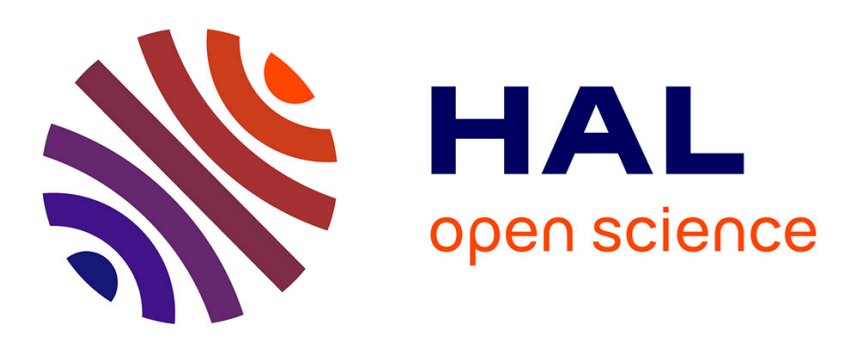

\title{
Shape and Dimension Estimations of Landslide Rupture Zones via Correlations of Characteristic Parameters
}

Gisela Domej, Céline Bourdeau Lombardi, Luca Lenti, Salvatore Martino, Kacper Pluta

\section{> To cite this version:}

Gisela Domej, Céline Bourdeau Lombardi, Luca Lenti, Salvatore Martino, Kacper Pluta. Shape and Dimension Estimations of Landslide Rupture Zones via Correlations of Characteristic Parameters. Geosciences, 2020, 10 (5), 23 p. 10.3390/geosciences10050198 . hal-03101674

\author{
HAL Id: hal-03101674 \\ https://hal.science/hal-03101674
}

Submitted on 7 Jan 2021

HAL is a multi-disciplinary open access archive for the deposit and dissemination of scientific research documents, whether they are published or not. The documents may come from teaching and research institutions in France or abroad, or from public or private research centers.
L'archive ouverte pluridisciplinaire HAL, est destinée au dépôt et à la diffusion de documents scientifiques de niveau recherche, publiés ou non, émanant des établissements d'enseignement et de recherche français ou étrangers, des laboratoires publics ou privés. 
Article

\title{
Shape and Dimension Estimations of Landslide Rupture Zones via Correlations of Characteristic Parameters
}

\author{
Gisela Domej ${ }^{1, *}$, Céline Bourdeau ${ }^{1}$, Luca Lenti ${ }^{1,2}$, Salvatore Martino ${ }^{3}$ (i) and Kacper Pluta ${ }^{4}$ \\ 1 Laboratoire SRO, Département GERS, Université Gustave Eiffel, 14-20 Boulevard Newton, \\ 77447 Marne-la-Vallée, France; celine.bourdeau-lombardi@univ-eiffel.fr (C.B.); \\ luca.lenti@univ-eiffel.fr (L.L.) \\ 2 Laboratoire MouvGS, Centre d'études et d'expertise sur les Risques, l'Environnement, \\ la Mobilité et l'Aménagement, 500 Route des Lucioles, 06903 Valbonne-Sophia Antipolis, France \\ 3 Dipartimento di Scienze della Terra \& Centro di Ricerca per i Rischi Geologici, Università Sapienza di Roma, \\ Piazzale Aldo Moro 5, 00185 Rome, Italy; salvatore.martino@uniroma1.it \\ 4 Computer Science Department, Technion-Israel Institute of Technology, Taub Building, \\ Haifa 3200003, Israel; kacper.pluta@gmail.com \\ * Correspondence: g.domej@gmail.com
}

Received: 7 April 2020; Accepted: 12 May 2020; Published: 21 May 2020

\begin{abstract}
For many geotechnical purposes, the proper estimation of shapes and dimensions of landslide rupture zones is of significant importance. Very often, this exact delineation is difficult due to the lack of information on rupture zone extents in 3D. Based on a global landslide inventory, this work presents statistical analyses correlating dimension-related and shape-related parameters characterizing a rupture zone in 3D to its volume. Dimension-related parameters are approximated by linear regressions increasing with greater volumes, whereas shape-related parameters appear stable throughout the entire range of volumes. Revealing themselves as very stable, these correlations can be used, hence, to extrapolate from a distinct parameter to the volume of a landslide rupture zone. In a second stage, ratios of dimension-related parameters are correlated with rupture zone volumes. Furthermore, this type of correlation delivers very stable results showing that ratios are constant throughout the entire range of volumes. Making use of this ratio consistency, it is possible to deduce one of the two parameters when the other one is given. This latter aspect seems to be promising for remote sensing surveys when initial rupture areas or rupture volumes should be delineated or for numerical modeling of landslides in 3D.
\end{abstract}

Keywords: landslide shape; landslide dimension; rupture zone; landslide size estimation; landslide database

\section{Introduction}

Across the globe, landslides are triggered by a variety of causes. They regularly lead to loss of life and damage, ranging from smaller to greater extent [1,2]. Common triggers are of tectonic, volcanic, meteorological, and anthropogenic nature or a combination of them [3,4]. As an example illustrating the trail of destruction serves the landslide series triggered during Hurricane Mitch in October 1998, which caused tremendous damage and 2000 fatalities in Nicaragua alone [5]. Another more recent example of devastation is the landslide series after the Sichuan Earthquake in May 2008, with a ten times higher number of victims $(20,000)[6]$.

Over the last decades, major contributions to a better understanding of the phenomenon of landslides in terms of, e.g., geographical localization, area and volume distributions, frequency, 
and probability analyses, as well as rupture mechanisms, were made by the establishment and consecutive exploration of landslide databases, which could be chronologic (i.e., listing landslides with different triggers over time) or event-based (i.e., listing landslides caused by a particular triggering event). The latter might be tectonic events (e.g., earthquakes, fault ruptures, or volcanic activity), meteorological events (e.g., heavy rain or storms), and climatic changes on a seasonal or long-term scale (e.g., snowmelt or permafrost degradation). Scientific work based on landslide databases with respect to the type of triggering events is exhaustive, and a full overview would be beyond the scope of this publication. Some examples are: studies using global, regional, and event-based databases of earthquake-triggered landslides by Harp and Jibson [7,8], Keefer et al. [9], Prestininzi and Romeo [10], Rodríguez et al. [11], and Tanyaş et al. [12]; studies based on landslide databases related to climatic changes such as snowmelt (e.g., [13]) and general climate change (e.g., [14]); and studies using event-based meteorological databases (e.g., [15]). An even more abundant number of studies on landslide databases became available due to the increasing reliability of remote sensing techniques, which allow for rapid mapping and analyses of single landslides or landslide clusters at different scales all over the globe.

In view of constant population growth and expansion to new and occasionally endangered living environments, proper management of landslide risk is essential for social resilience. In addition, climate change is not to be disdained in this context, as frequency and intensity of extreme meteorological events are expected to increase, which, in turn, can trigger numerous landslides.

Relating to event magnitude and successive consequences, the volume of landslides is considered as one of the most significant parameters [16], which becomes apparent, e.g., when comparing unequal damage potentials of small and frequent events with large and rare events. Exact estimates for landslide volumes are, however, among the most difficult parameters to assess.

Following this essential need for detailed volume assessment of landslides, this publication presents statistical analyses focusing on expected dimensions and shapes of landslide rupture zones in 3D. The term "rupture zone" refers here to the landslide volume that is confined by the rupture surface at the moment of the main rupture event (Figure 1a-d). In contrast to other authors (e.g., [16-23]), who consider landslide zones as the entire zone affected by sliding processes for different purposes (e.g., mapping and inventory work for statistical applications, area-to-volume and area-to-depth correlations, or probability and frequency analyses), this work clearly distinguishes the entire landslide zone from the zone confining the rupture volume of landslides. As the Frank Landslide, Canada (No. 019.00 in Table A1 in the Appendix A), in Figure 2 illustrates, the distinction of both zones implies significant differences in terms of area and volume. Another difference to common landslide inventories is that, here, many more depth-related parameters are available delimiting the rupture zone at different locations, whereas other authors use a single multiplier to account for depth extents (e.g., [24-28]). Both aspects might be of particular interest for application in remote sensing or numerical landslide modeling.

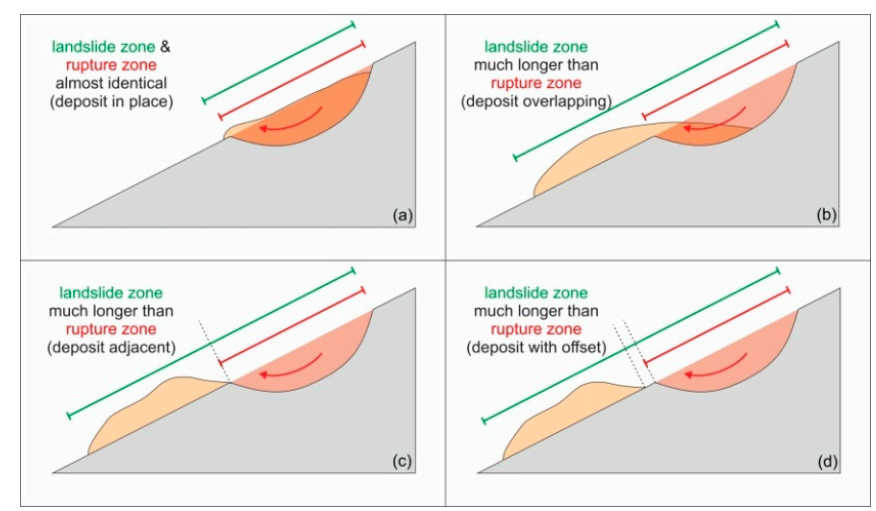

Figure 1. Comparison (identical (a), overlap (b), adjacent (c), and offset (d)) of rupture zones and landslide zones (i.e., entire zones affected by sliding processes, which are mainly dependent on the location of the landslide deposits). 


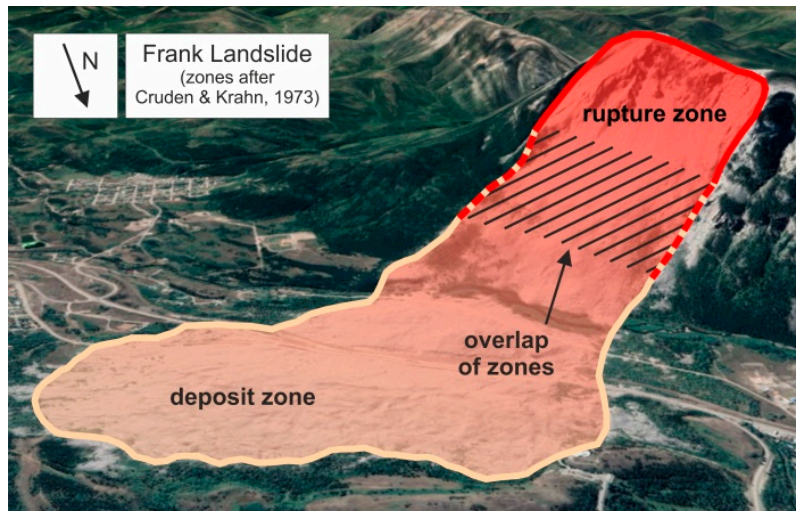

Figure 2. Difference between the entire landslide zone and the rupture zone exemplified by the Frank Landslide, Canada (No. 019.00 in Table A1 in the Appendix A). Zones are drawn after Cruden and Krahn [29] (satellite imagery from Google Earth Pro [30]).

Statistical analyses are based on a newly created chronologic database presented by Domej et al. [31] comprising 277 landslides in 40 countries across the globe (Figure 3), which will be revisited in the first part of this publication. The second part is dedicated to statistical analyses consisting of correlations between landslide volumes and single parameters characterizing landslide rupture zones and of correlations between landslide volumes and ratios of single parameters. The last section discusses results as well as their potential fields of application. All landslides included in the database are listed with their date, location, and trigger in Table A1 in the Appendix A. Initially designed for seismically induced landslides, the database consists majorly, but by far not exclusively, of earthquake-triggered landslides; triggers also range from precipitation, storms, and anthropogenic influence to unknown causes.

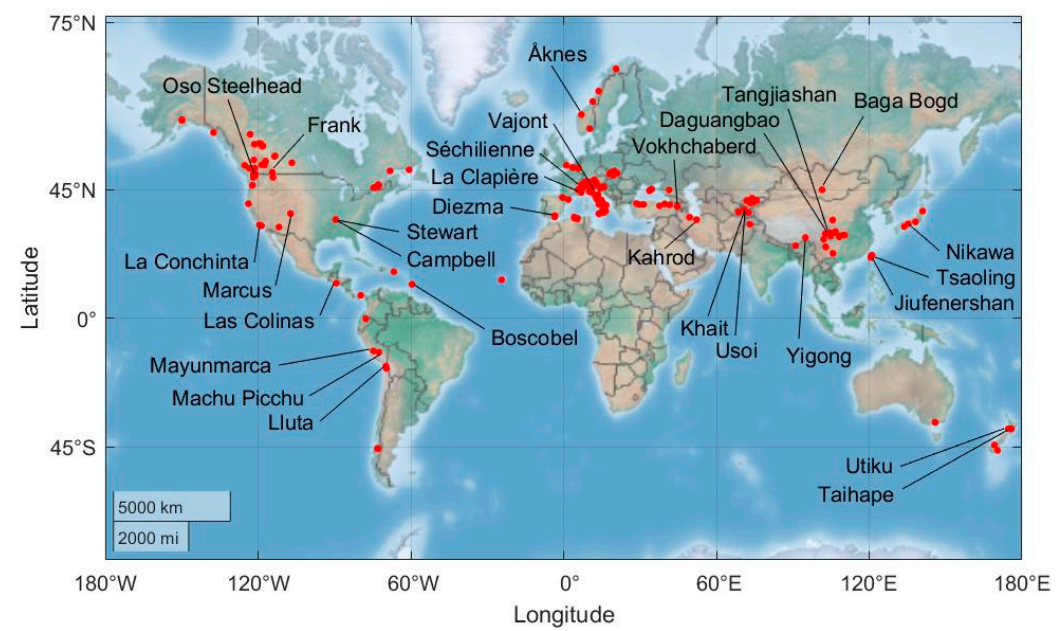

Figure 3. Locations of the 277 landslides included in the database (map from MATLAB [32]).

\section{Statistical Analyses}

The analyses aim for a general understanding of the statistical behavior of geometrical parameters characterizing landslide rupture zones (Figure 4) with increasing landslide sizes.

In theory, i.e., if the data coverage is fully exhaustive, a total number of 66 parameters and descriptive notes with respect to longitudinal cross sections (LCS), transversal cross sections (TCS) and top views (maps) are available for each landslide included in the database; they are adapted and further developed from the parameters proposed by the IAEG Commission on Landslides [33]. Individual parameters that are used for the here presented analyses are listed in Table 1 and can be either directly or indirectly derived from available publications. Direct parameters are those that are measured from 
LCS, TCS, and/or maps published per respective landslide. Indirect parameters are those that are calculated via equations using direct parameters (Table 1$)$. The calculated volume $\left(V_{\text {equ }}\right)$ is derived from the equation of Cruden and Varnes [34] as half an ellipsoid (Figure 4) approximating landslides. The curvature - taken as the difference between the angles at points 0 and $\mathrm{E}\left(\delta_{0}\right.$ and $\left.\delta_{\mathrm{E}}\right)$-is not an international standard, but was adopted by the authors; the higher the difference is, the higher is the curvature (Figure 4 ). Being defined via a simple height-over-length-tangent, the calculated slope angle $\left(\alpha_{\text {equ }}\right)$ also represents the mean slope angle of the rupture zone (Figure 4 ). The perspective of the TCS represents a view from the landslide toe towards the landslide crest. An example of the measurements of the parameters characterizing the rupture zone is shown in Figure 5 using the Diezma Landslide, Spain (No. 001.00 in Table A1 in the Appendix A).

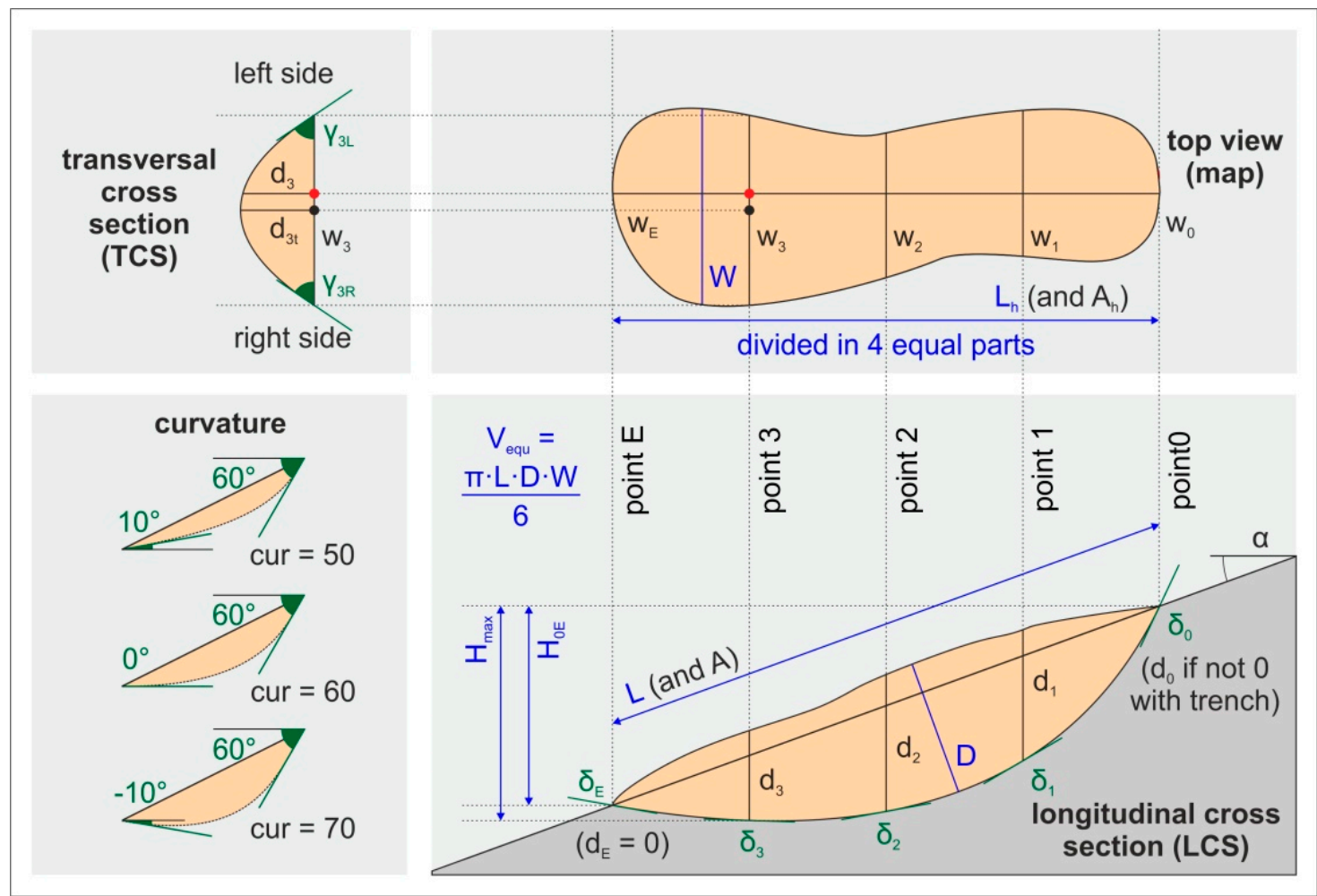

Figure 4. Description of parameters defining a landslide rupture zone (adapted and further developed from the IAEG Commission on Landslides [33]).

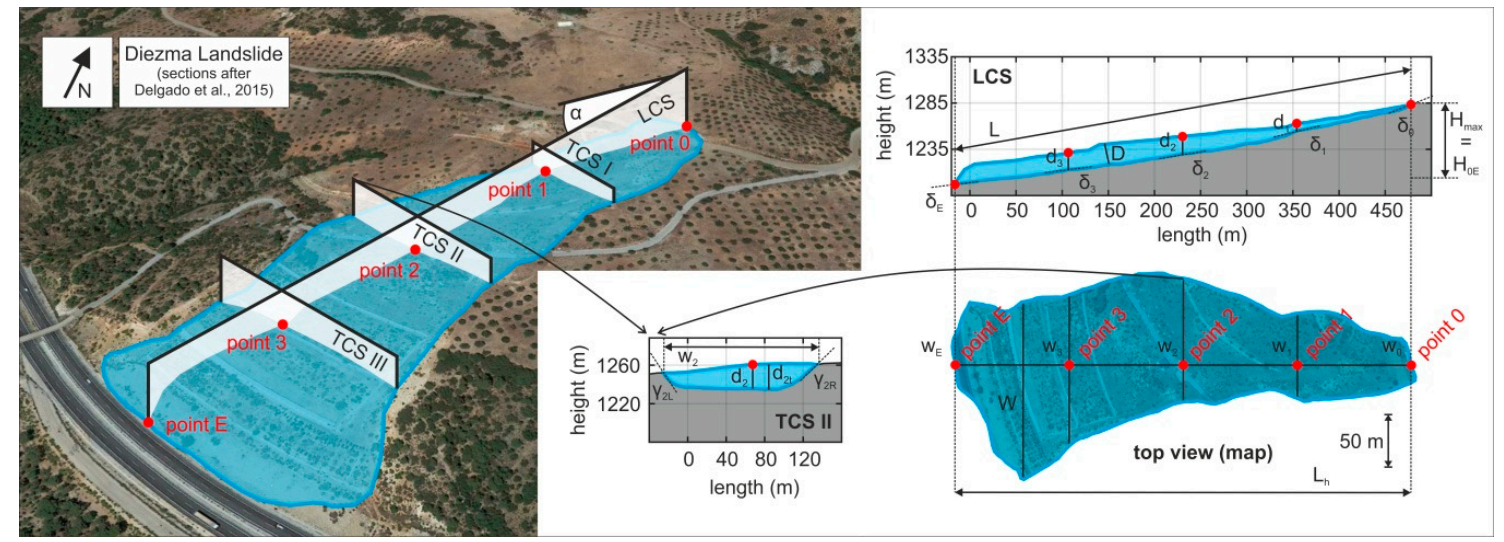

Figure 5. Schematic example of measurement of the parameters defining the rupture zone of the Diezma Landslide, Spain (No. 001.00 in Table A1 in the Appendix A). Cross sections are drawn after Delgado et al. [35] (satellite imagery from Google Earth Pro [36]). 
Table 1. Description of parameters defining a landslide rupture zone (adapted and further developed from the IAEG Commission on Landslides [33]). The last column indicates the type of statistical distribution of values per individual parameter throughout the database.

\begin{tabular}{|c|c|c|}
\hline Parameters & Description & Statistical Distribution \\
\hline$V_{\text {equ }}$ & calculated volume $(=(1 / 6) \cdot \pi \cdot L \cdot D \cdot W))$ & increasing exponential \\
\hline A & area as reported by literature & increasing exponential \\
\hline$A_{h}$ & area projected to the horizontal & increasing exponential \\
\hline $\mathrm{L}$ & length along the slope & increasing exponential \\
\hline $\mathrm{L}_{\mathrm{h}}$ & length projected to the horizontal & increasing exponential \\
\hline $\mathrm{H}_{\max }$ & height between point 0 and the deepest point & increasing exponential \\
\hline $\mathrm{H}_{0 \mathrm{E}}$ & height between point 0 and point $\mathrm{E}$ & increasing exponential \\
\hline W & maximum width & increasing exponential \\
\hline $\mathrm{w}_{0}, \mathrm{w}_{1}, \mathrm{w}_{2}, \mathrm{w}_{3}, \mathrm{w}_{\mathrm{E}}$ & widths at points 0 to $\mathrm{E}$ & increasing exponential \\
\hline D & maximum depth & increasing exponential \\
\hline $\mathrm{d}_{0}, \mathrm{~d}_{1}, \mathrm{~d}_{2}, \mathrm{~d}_{3},\left(\mathrm{~d}_{\mathrm{E}}\right)$ & depths at points 0 to $E$ & normal ( $\mathrm{d}_{\mathrm{E}}$ is always 0$)$ \\
\hline$\delta_{0}, \delta_{1}, \delta_{2}, \delta_{3}, \delta_{\mathrm{E}}$ & angles at points 0 to $\mathrm{E}$ & normal \\
\hline cur & curvature of the rupture surface $\left(=\delta_{0-} \delta_{\mathrm{E}}\right)$ & normal \\
\hline$\alpha_{\text {lit }}$ & reported slope angle & normal \\
\hline$\alpha_{\text {equ }}$ & calculated slope angle $\left(=\tan ^{-1}\left(\mathrm{H}_{0 \mathrm{E}} / \mathrm{L}_{\mathrm{h}}\right)\right)$ & normal \\
\hline$d_{1 t}, d_{2 t}, d_{3 t}$ & maximum depths of TCS I to III & \\
\hline$\gamma_{1 \mathrm{~L}}, \gamma_{2 \mathrm{~L}}, \gamma_{3 \mathrm{~L}}$ & left flank angles of TCS I to III & (ICS: too few data; \\
\hline$\gamma_{1 R}, \gamma_{2 R}, \gamma_{3 R}$ & right flank angles of TCS I to III & \\
\hline
\end{tabular}

Usually, the number of evaluable parameters decreases due to the availability of data throughout the database. For $80 \%$ of all landslides in the database, a map is available, for $71 \%$ there is an LCS, and for $61 \%$ there are both a map and an LCS. Only two of the 277 landslides have an exhaustive TCS record. Therefore, parameters that are derived from the respective imagery show different recurrences. All parameters, except the areas $\left(A\right.$ and $\left.A_{h}\right)$ and the reported slope angle $\left(\alpha_{\text {lit }}\right)$, have a recurrence of $70 \%$ or higher throughout the database. This ensures sufficient data availability for exactly those parameters that are most interesting to analyze regarding shapes and dimensions of landslide rupture zones, not only superficially, but also with respect to the extent of the depth.

The analyses follow the approach of simple volume-to-parameter correlation and volume-to-ratio correlation (Figure 6). Although being the most complexly interlinked indirect parameter, the calculated volume $\left(\mathrm{V}_{\text {equ }}\right)$ was chosen as the first variable of correlation, which is justified by its strikingly high recurrence or $74 \%$. The reported volume ( $\mathrm{V}_{\text {lit }}$; not used in this work and not mentioned in Table 1$)$, in contrast, has a recurrence of only $60 \%$, and covers in many cases also parts of the deposit volumes which conflicts with the exclusive assessment of the rupture zone. The argument that the equation of Cruden and Varnes [34] is suitable for rotational slides while misestimating volumes of translational and roto translational geometries, could at least in this work be rebutted. Where the reported volume $\left(\mathrm{V}_{\text {lit }}\right)$ and the calculated volume $\left(\mathrm{V}_{\text {equ }}\right)$ clearly refer to the rupture zone, comparisons of the two volume types do not indicate a notable difference [31]. 


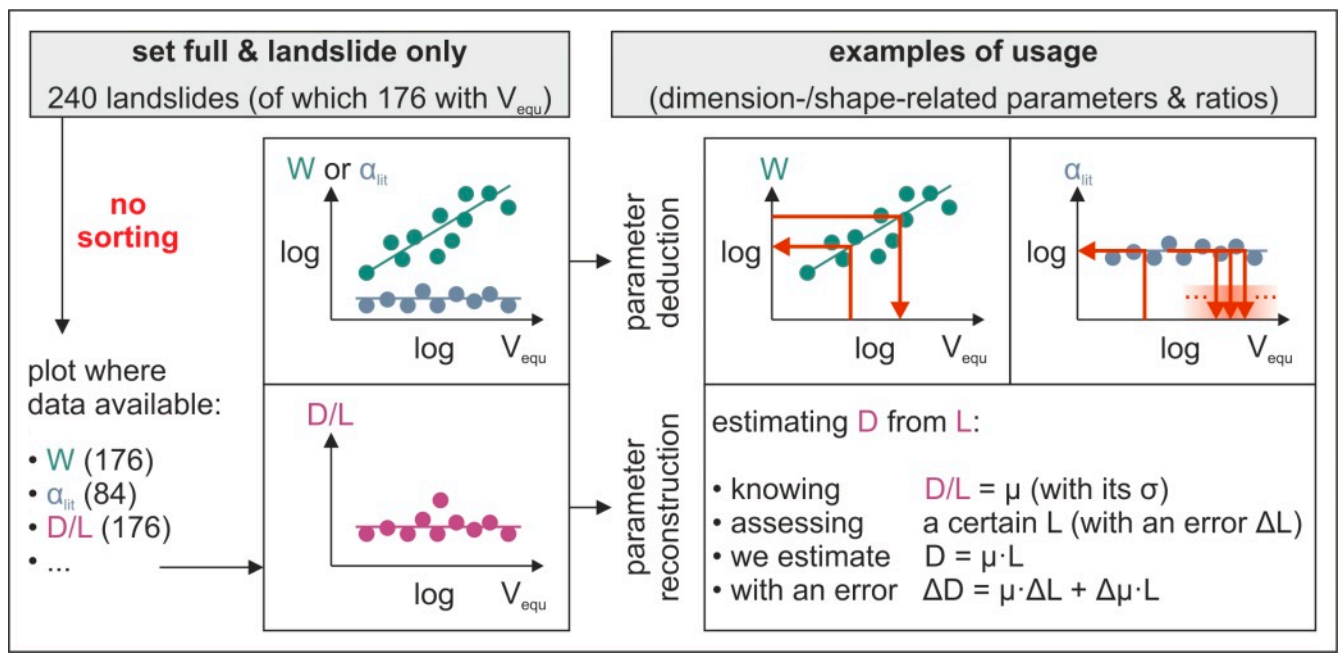

Figure 6. Schematic representation of the statistical approach. Landslides of a particular set are screened for showing a calculated volume $\left(\mathrm{V}_{\text {equ }}\right)$. Those that also show a variable of correlation (e.g., maximum depth (D), reported slope angle $\left(\alpha_{\text {lit }}\right)$, or the ratio of the maximum width and the length along the slope $(\mathrm{W} / \mathrm{L}))$ are then used for plots that illustrate the respective correlation. The right part of the figure shows examples of usage of the established correlations.

\subsection{Volume-to-Parameter Correlations}

One of the two approaches that allow for statistical analyses of the behavior of dimension- and shape-related parameters consists of volume-to-parameter correlations. One variable of correlation is necessarily the calculated volume $\left(\mathrm{V}_{\text {equ }}\right)$, whereas the place of the second variable of correlation is taken by any of the parameters characterizing the rupture zone in 3D (Figure 4, Table 1).

Here, the choice of suitable variables of correlation is limited by reflections on sample sizes and meaningfulness. Considering the set "full/landslide only", sample sizes for different parameters vary as a function of the applied filter cascade (Table 2). The term "landslide" refers here to classic landslides sliding on actual sliding surfaces, not displaying local features of other mass movement types such as rock falls, topples, or earth flows [37]. Thereupon apply the filters for the two variables of correlation as uniquely those landslide records showing the calculated volume $\left(\mathrm{V}_{\text {equ }}\right)$, as well as the respective parameter of interest, can be used for evaluation (Figure 6). For the shape-related parameters, the calculated slope angle $\left(\alpha_{\text {equ }}\right)$, the angles at points 0 to $\mathrm{E}\left(\delta_{0}\right.$ to $\left.\delta_{\mathrm{E}}\right)$, and the curvature (cur), the thereby obtained sample sizes are very satisfying and vary between 153 and 176 cases (second columns of Tables 3 and 4). The reported slope angle $\left(\alpha_{1 i t}\right)$ is to be evaluated for 84 cases, both area types (the reported area (A) and its projection to the horizontal $\left.\left(\mathrm{A}_{h}\right)\right)$ are represented only by 72 cases. All TCS related parameters are quasi-nonrepresented by solely three cases at the maximum and, hence, not considered for the analyses (Table 1). The choice to filter according to rotational (i.e., rather half-elliptical shapes; e.g., Figure 4), translational (i.e., rather flat shapes; e.g., Figure 5) and roto-translational rupture zones is explained by the fact that this information is available for every landslide included in the database. The filter, hence, does not reduce the sample sizes.

Table 2. Subsets of the database used for analyses with their respective first and second filters.

\begin{tabular}{cccc}
\hline Set & Filter 1 & Filter 2 & Included Cases \\
\hline 1-“full" & - & & 240 \\
2-“SR" & landslides in seismic regions & & 189 \\
3-“EQt" & earthquake-triggered landslides & landslide only & 95 \\
4-“full-R" & rotational landslides & & 76 \\
5-“full-T" & translational landslides & 79 \\
6-"full-RT" & roto-translational & 85 \\
\hline
\end{tabular}


Table 3. Results for the volume-to-parameter correlations for the set "full". For all dimension and shape-related parameters, the regression parameters ( $\mathrm{R}^{2}$, RMSE, constant (a) and factor (b) with their 95\% confidence intervals; Equation (2)) are given.

\begin{tabular}{|c|c|c|c|c|c|c|}
\hline $\mathrm{V}_{\text {equ}} /$ & Cases & & $\mathrm{R}^{2}$ & RMSE & Constant (a) & Factor (b) \\
\hline $\mathrm{D}$ & 176 & & 0.75 & 0.22 & $-0.29( \pm 0.18)$ & $0.29( \pm 0.02)$ \\
\hline $\mathrm{d}_{\mathrm{av} 5}$ & 153 & & 0.75 & 0.23 & $-0.65( \pm 0.20)$ & $0.29( \pm 0.03)$ \\
\hline $\mathrm{d}_{\mathrm{av} 4}$ & 153 & & 0.75 & 0.23 & $-0.55( \pm 0.20)$ & $0.29( \pm 0.03)$ \\
\hline $\mathrm{d}_{\mathrm{av} 3}$ & 153 & & 0.75 & 0.23 & $-0.46( \pm 0.20)$ & $0.30( \pm 0.03)$ \\
\hline $\mathrm{d}_{0}$ & 153 & & \multicolumn{4}{|c|}{$d_{0}$ contains 0 , not fitted in a log-log } \\
\hline $\mathrm{d}_{1}$ & 153 & & 0.73 & 0.24 & $-0.41( \pm 0.21)$ & $0.30( \pm 0.03)$ \\
\hline$d_{2}$ & 153 & 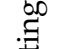 & 0.71 & 0.25 & $-0.37( \pm 0.21)$ & $0.29( \pm 0.03)$ \\
\hline$d_{3}$ & 153 & $\underset{ت}{ \pm}$ & 0.66 & 0.30 & $-0.63( \pm 0.25)$ & $0.31( \pm 0.04)$ \\
\hline $\mathrm{d}_{\mathrm{E}}$ & 153 & $\mathscr{U}$ & \multicolumn{4}{|c|}{$\mathrm{d}_{\mathrm{E}}$ is always 0 , not fitted in a log-log } \\
\hline $\mathrm{H}_{0 \mathrm{E}}$ & 176 & $\mathcal{\Xi}$ & 0.60 & 0.34 & $-0.06( \pm 0.28)$ & $0.32( \pm 0.04)$ \\
\hline $\mathrm{H}_{\max }$ & 176 & $\vec{z}$ & 0.63 & 0.32 & $-0.06( \pm 0.26)$ & $0.33( \pm 0.04)$ \\
\hline $\mathrm{L}$ & 176 & 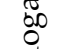 & 0.88 & 0.17 & $0.32( \pm 0.14)$ & $0.36( \pm 0.02)$ \\
\hline $\mathrm{L}_{\mathrm{h}}$ & 176 & $\bar{d}$ & 0.88 & 0.17 & $0.27( \pm 0.14)$ & $0.36( \pm 0.02)$ \\
\hline W & 176 & $\frac{10}{2}$ & 0.82 & 0.21 & $0.25( \pm 0.17)$ & $0.36( \pm 0.02)$ \\
\hline $\mathrm{w}_{\mathrm{av} 5}$ & 169 & $\frac{\sigma}{0}$ & 0.80 & 0.22 & $0.15( \pm 0.19)$ & $0.35( \pm 0.03)$ \\
\hline $\mathrm{w}_{\mathrm{av} 3}$ & 169 & & 0.81 & 0.22 & $0.23( \pm 0.18)$ & $0.35( \pm 0.03)$ \\
\hline $\mathrm{w}_{0}$ & 169 & & 0.57 & 0.36 & $0.02( \pm 0.30)$ & $0.32( \pm 0.04)$ \\
\hline $\mathrm{w}_{1}$ & 169 & & 0.78 & 0.24 & $0.23( \pm 0.19)$ & $0.34( \pm 0.03)$ \\
\hline $\mathrm{w}_{2}$ & 169 & & 0.78 & 0.24 & $0.25( \pm 0.20)$ & $0.34( \pm 0.03)$ \\
\hline $\mathrm{w}_{3}$ & 169 & & 0.78 & 0.24 & $0.21( \pm 0.20)$ & $0.35( \pm 0.03)$ \\
\hline$w_{E}$ & 169 & & 0.63 & 0.35 & $-0.02( \pm 0.29)$ & $0.36( \pm 0.04)$ \\
\hline$\delta_{0}^{L}$ & 153 & & 0.03 & 19.21 & $67.00( \pm 16.35)$ & $-2.36( \pm 2.28)$ \\
\hline$\delta_{1}$ & 153 & 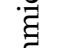 & 0.02 & 13.99 & $28.32( \pm 11.90)$ & $-1.41( \pm 1.66)$ \\
\hline$\delta_{2}$ & 153 & 至 & 0.00 & 13.97 & $17.06( \pm 11.88)$ & $-0.32( \pm 1.66)$ \\
\hline$\delta_{3}$ & 153 & $\begin{array}{l}\vec{E} \\
0\end{array}$ & 0.00 & 11.58 & $8.59( \pm 09.85)$ & $0.32( \pm 1.38)$ \\
\hline$\delta_{\mathrm{E}}$ & 153 & $\frac{0}{1}$ & 0.00 & 16.92 & $0.15( \pm 14.39)$ & $-0.16( \pm 2.01)$ \\
\hline cur & 153 & 吾 & 0.01 & 25.26 & $66.84( \pm 21.50)$ & $-2.21( \pm 3.00)$ \\
\hline$\alpha_{\mathrm{equ}}$ & 176 & $\vec{\infty}$ & 0.01 & 11.71 & $22.86( \pm 09.53)$ & $-0.70( \pm 1.35)$ \\
\hline$\alpha_{\text {lit }}$ & 84 & & 0.00 & 13.31 & $19.96( \pm 16.23)$ & $-0.01( \pm 2.32)$ \\
\hline
\end{tabular}

Table 4. Results for the volume-to-parameter correlations for the set "full". For all shape-related parameters, the mean value $(\mu)$ with the respective standard deviation $(\sigma)$ and the sample size per sigma interval is given.

\begin{tabular}{cccccccc}
\hline $\mathbf{V}_{\text {equ }} /$ & Cases & $\mu$ & $\boldsymbol{\sigma}$ & $\boldsymbol{\mu} / \boldsymbol{\sigma}$ & $\mathbf{\%}$ in $\pm \mathbf{1 \sigma}$ & $\mathbf{\%}$ in $\pm \mathbf{2 \sigma}$ & $\mathbf{\%}$ in $\pm \mathbf{3 \sigma}$ \\
\hline$\delta_{0}$ & 153 & 50.37 & 19.41 & 2.59 & $66.0 \%$ & $97.4 \%$ & $100.0 \%$ \\
$\delta_{1}$ & 153 & 18.42 & 14.07 & 1.31 & $66.7 \%$ & $96.7 \%$ & $100.0 \%$ \\
$\delta_{2}$ & 153 & 14.83 & 13.93 & 1.06 & $76.5 \%$ & $94.1 \%$ & $98.7 \%$ \\
$\delta_{3}$ & 153 & 10.81 & 11.55 & 0.94 & $82.4 \%$ & $94.8 \%$ & $98.7 \%$ \\
$\delta_{\mathrm{E}}$ & 153 & -0.96 & 16.86 & -0.06 & $73.9 \%$ & $94.1 \%$ & $98.0 \%$ \\
cur & 153 & 51.33 & 25.36 & 2.02 & $70.6 \%$ & $97.4 \%$ & $99.4 \%$ \\
$\alpha_{\text {equ }}$ & 176 & 17.99 & 11.71 & 1.54 & $71.0 \%$ & $94.3 \%$ & $98.9 \%$ \\
$\alpha_{\text {lit }}$ & 84 & 19.90 & 13.23 & 1.50 & $73.8 \%$ & $97.6 \%$ & $98.8 \%$ \\
\hline
\end{tabular}

As for the reported area $(A)$ and its projection to the horizontal $\left(A_{h}\right)$, one might criticize that despite their good representation, they are not included in the volume-to-parameter correlations. Here the argument is that area reports on landslides are to be seen with caution, especially when it comes explicitly to the delineation of rupture zones. Rupture and runout zones can be overlapping, adjacent, or even separated (Figure 1a-d); very often, reported areas refer to the entire area across a slope, which is affected by the sliding process. For several landslides in the database, the distinction between these different area types is not clear, and thus correlations were dismissed. Another argument is that this very uncertainty might become a field of application of the presented statistical correlations. 
In contrast to the sifting of unsuitable variables of correlation, also a few new appropriate parameters were also created. They might become of particular interest when delineating average dimensions of rupture zones rather than maximal possible extents in particular locations of rupture zones.

- $\mathrm{d}_{\mathrm{av} 5}$ : average depth of the rupture zone below points

- $\mathrm{d}_{\mathrm{av} 4}$ : average depth of the rupture zone below points

$0,1,2,3, \mathrm{E}$

- $\mathrm{d}_{\mathrm{av} 3}:$ average depth of the rupture zone below points

$0,1,2,3$

- $\mathrm{w}_{\mathrm{av} 5}$ :

average width of the rupture zone at points

$1,2,3$

- $\mathrm{w}_{\mathrm{av} 3}$ :

$0,1,2,3, \mathrm{E}$

$1,2,3$

Expecting variable statistical behaviors throughout dimension and shape-related parameters after initial data cloud inspection, fitting tests of different distribution types were applied to each parameter distribution with MATLAB's Curve Fitting Tool [32]. It appeared that for the climbing trend-prone dimension-related parameters, the best results were obtained by fittings of linear regressions, i.e., of polynomials of the first degree in double-logarithmic diagrams. For the shape-related parameters visibly lacking a climbing trend, such linear regressions were nevertheless "forced" on data clouds in x-semi-logarithmic diagrams with very unsatisfactory results regarding the fitting (i.e., $\mathrm{R}^{2}$ almost 0 and significantly high RMSE). Furthermore, the polynomial factors within these "forced" regressions tended to be low, which emphasized the representation of the respective data clouds by their mean values $(\mu)$. Taking into account that both dimension- and shape-related parameters exist within the volume-to-parameter correlations (Tables 3 and 4), a homogeneous way of analyses had to be adopted. For internal consistency, hence, all distributions of dimension-related parameters underwent the fitting of linear regressions in double-logarithmic diagrams, whereas, for all distributions of shape-related parameters, the mean value $(\mu)$ was calculated. Furthermore, the homogeneity of analyses between the concerned volume-to-parameter correlations and the likewise shape-based volume-to-ratio correlations (Table 5; next subsection) was preserved.

In the following, the analytical procedure for the most comprehensive set "full" is described. It should be mentioned beforehand that the identical procedure was carried out also for all other sets (Table 2) in order to observe potential changes in statistical behaviors. A comparison of the results of all six tested sets is given in the discussion.

Regressions are here of the general type

$$
\mathrm{y}=10^{\mathrm{a}} \mathrm{V}_{\text {equ }}{ }^{\mathrm{b}},
$$

and appear in a double-logarithmic diagram as

$$
\log _{10}(y)=a+b \cdot \log _{10}\left(V_{\text {equ }}\right),
$$

with y defining the respective parameter, a representing the intercept on the $y$-axis (herein after called "constant") and b defining the gradient (herein after called "factor").

Examples of regression fittings are shown in Figure 7a-c for the set "full" for the maximum depth (D), the height between the point 0 and the point $\mathrm{E}\left(\mathrm{H}_{0 \mathrm{E}}\right)$, and the length along the slope (L). Despite different scatter patterns, all data clouds reveal a clear increasing tendency. Regressions fit with a few exceptions with coefficients of determination $\left(\mathrm{R}^{2}\right)$ above or equal to the typical threshold of acceptance of 0.7 (Table 3). Furthermore, within the other five tested sets (Table 2), all regressions fit with similar coefficients of determination $\left(R^{2}\right)$. Thus, regression fitting seems to be an adequate tool for correlating calculated volumes $\left(\mathrm{V}_{\text {equ }}\right)$ and dimension-related parameters. Results for the set "full" are listed in Table 3. The last two columns give the constant (a) as well as the factor (b) that must be inserted into Equation (2) in order to reproduce the straight line per parameter in the respective double-logarithmic diagram. 
Table 5. Results for volume-to-ratio correlations for the set "full". For all shape-related parameters (i.e., here the ratios), the mean values $(\mu)$ with the respective standard deviations $(\sigma)$ and the sample sizes per sigma interval are given.

\begin{tabular}{|c|c|c|c|c|c|c|c|}
\hline $\mathrm{V}_{\text {equ/ }}$ & Cases & $\mu$ & $\sigma$ & $\mu / \sigma$ & $\%$ in $\pm 1 \sigma$ & $\%$ in $\pm 2 \sigma$ & $\%$ in $\pm 3 \sigma$ \\
\hline $\mathrm{H}_{0 \mathrm{E}} / \mathrm{L}_{\mathrm{h}}$ & 176 & 0.35 & 0.27 & 1.29 & $82.4 \%$ & $94.3 \%$ & $98.3 \%$ \\
\hline $\mathrm{H}_{\max } / \mathrm{L}_{\mathrm{h}}$ & 176 & 0.36 & 0.27 & 1.34 & $82.4 \%$ & $94.9 \%$ & $98.3 \%$ \\
\hline $\mathrm{H}_{0 \mathrm{E}} / \mathrm{W}$ & 176 & 0.49 & 0.51 & 0.96 & $88.6 \%$ & $96.0 \%$ & $97.7 \%$ \\
\hline $\mathrm{H}_{0 \mathrm{E}} / \mathrm{w}_{\mathrm{av} 5}$ & 169 & 0.72 & 0.77 & 0.93 & $88.2 \%$ & $95.9 \%$ & $97.6 \%$ \\
\hline $\mathrm{H}_{0 \mathrm{E}} / \mathrm{w}_{\mathrm{av} 3}$ & 169 & 0.62 & 0.69 & 0.90 & $88.8 \%$ & $95.3 \%$ & $98.2 \%$ \\
\hline $\mathrm{H}_{0 \mathrm{E}} / \mathrm{D}$ & 176 & 3.92 & 3.42 & 1.15 & $85.2 \%$ & $97.7 \%$ & $98.3 \%$ \\
\hline $\mathrm{H}_{0 \mathrm{E}} / \mathrm{d}_{\mathrm{av} 5}$ & 153 & 7.85 & 5.84 & 1.34 & $85.0 \%$ & $93.5 \%$ & $97.4 \%$ \\
\hline $\mathrm{H}_{0 \mathrm{E}} / \mathrm{d}_{\mathrm{av} 4}$ & 153 & 6.28 & 4.67 & 1.34 & $85.0 \%$ & $93.5 \%$ & $97.4 \%$ \\
\hline $\mathrm{H}_{0 \mathrm{E}} / \mathrm{d}_{\mathrm{av} 3}$ & 153 & 4.87 & 3.62 & 1.35 & $83.7 \%$ & $94.8 \%$ & $97.4 \%$ \\
\hline $\mathrm{D} / \mathrm{L}$ & 176 & 0.11 & 0.09 & 1.31 & $81.3 \%$ & $90.3 \%$ & $99.4 \%$ \\
\hline $\mathrm{d}_{\mathrm{av} 5} / \mathrm{L}$ & 153 & 0.05 & 0.03 & 1.46 & $75.8 \%$ & $94.1 \%$ & $99.4 \%$ \\
\hline $\mathrm{d}_{\mathrm{av} 4} / \mathrm{L}$ & 153 & 0.06 & 0.04 & 1.45 & $75.8 \%$ & $94.1 \%$ & $99.4 \%$ \\
\hline $\mathrm{d}_{\mathrm{av} 3} / \mathrm{L}$ & 153 & 0.08 & 0.06 & 1.45 & $74.5 \%$ & $94.1 \%$ & $99.4 \%$ \\
\hline $\mathrm{W} / \mathrm{L}$ & 176 & 1.17 & 1.38 & 0.85 & $92.1 \%$ & $97.2 \%$ & $97.7 \%$ \\
\hline $\mathrm{w}_{\mathrm{av} 5} / \mathrm{L}$ & 169 & 0.82 & 0.90 & 0.91 & $89.9 \%$ & $97.0 \%$ & $98.2 \%$ \\
\hline $\mathrm{w}_{\mathrm{av} 3} / \mathrm{L}$ & 169 & 0.95 & 1.01 & 0.95 & $91.1 \%$ & $97.0 \%$ & $98.2 \%$ \\
\hline $\mathrm{D} / \mathrm{W}$ & 176 & 0.15 & 0.14 & 1.02 & $89.2 \%$ & $94.3 \%$ & $97.2 \%$ \\
\hline $\mathrm{D} / \mathrm{w}_{\text {av } 5}$ & 169 & 0.21 & 0.19 & 1.10 & $87.0 \%$ & $94.7 \%$ & $97.6 \%$ \\
\hline $\mathrm{D} / \mathrm{w}_{\mathrm{av} 3}$ & 169 & 0.17 & 0.16 & 1.07 & $88.2 \%$ & $95.3 \%$ & $98.8 \%$ \\
\hline $\mathrm{d}_{\mathrm{av} 5} / \mathrm{W}$ & 153 & 0.07 & 0.08 & 0.89 & $92.8 \%$ & $97.4 \%$ & $97.4 \%$ \\
\hline $\mathrm{d}_{\mathrm{av} 4} / \mathrm{W}$ & 153 & 0.09 & 0.10 & 0.89 & $92.8 \%$ & $97.4 \%$ & $97.4 \%$ \\
\hline $\mathrm{d}_{\mathrm{av} 3} / \mathrm{W}$ & 153 & 0.11 & 0.13 & 0.89 & $92.8 \%$ & $97.4 \%$ & $98.0 \%$ \\
\hline $\mathrm{d}_{\mathrm{av} 5} / \mathrm{w}_{\mathrm{av} 5}$ & 146 & 0.10 & 0.10 & 0.92 & $94.5 \%$ & $98.6 \%$ & $98.6 \%$ \\
\hline $\mathrm{d}_{\mathrm{av} 3} / \mathrm{w}_{\mathrm{av} 3}$ & 146 & 0.13 & 0.16 & 0.84 & $93.8 \%$ & $98.6 \%$ & $98.6 \%$ \\
\hline
\end{tabular}

Conclusions on dispersion are to be regarded with caution in the case of dimension-related parameters. The main reason is that each point in the data clouds depends only on one value of the calculated volume $\left(\mathrm{V}_{\text {equ }}\right)$; i.e., there is no option to measure dispersions per distinct volume.

The analytical procedure for shape-related parameters (Table 4) consisted of averaging the values represented by the respective data clouds, since "forced" regression fitting in x-semi-logarithmic diagrams resulted in low factors (b), $R^{2}$ close to 0 , and significantly high RMSE (Figure $7 d$, Table 3). Besides the assumption of consistency throughout different calculated volumes $\left(\mathrm{V}_{\text {equ }}\right)$, there is also a second strong argument favoring simple value averaging instead of regression fitting. Considering perfectly normally distributed data, specific fractions of it should lie within symmetric belts of two $( \pm 1 \sigma)$, four $( \pm 2 \sigma)$ and six $( \pm 3 \sigma)$ standard deviations around the mean value $(\mu)$. In the case of the set "full", data of the individual shape-related parameters follow these suggested intervals with minor deviations (Table 4). One can assume, hence, that data of shape-related parameters are normally distributed what emphasizes the representativeness of the respective mean value $(\mu)$. Also, the other five tested sets (Table 2) reveal very similar tendencies with respect to the required fraction of data within the three symmetric belts; only in six cases, sigma interval thresholds were missed by more than $5 \%$.

An example of averaging values is shown in Figure $7 \mathrm{~d}$ for the set "full" for the calculated slope angle $\left(\alpha_{\text {equ }}\right)$, which shows a slight decreasing tendency for very great calculated volumes $\left(V_{\text {equ }}\right)$. This phenomenon is probably due to the fact that slopes cannot become infinitely high. Overall, the mean value $(\mu)$ seems, however, representative.

All mean values $(\mu)$ are listed in Table 4 , together with their standard deviations $(\sigma)$ and the relations between both types of values $(\mu / \sigma)$ as a measure for dispersion. Here, the information about dispersion is of much bigger interest than the dimension-related parameters. 

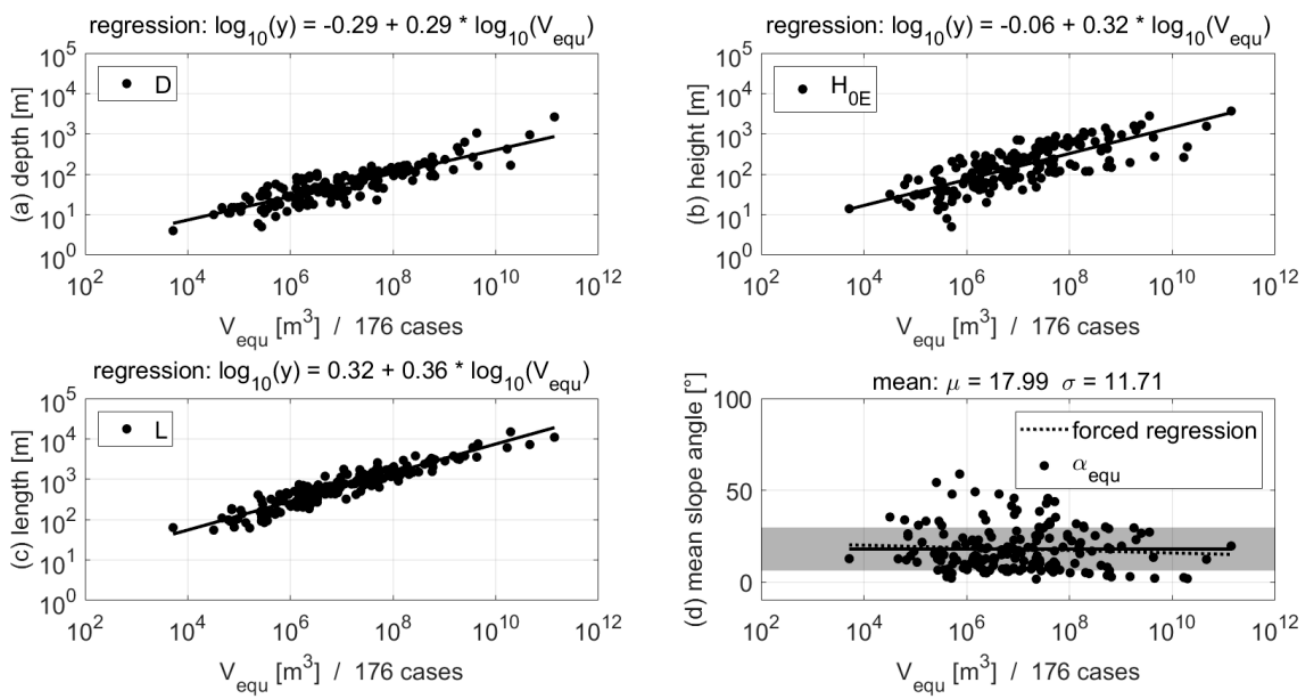

Figure 7. Examples of volume to parameter correlations for the set "full". Dimension-related parameters $\left(\mathrm{D}(\mathbf{a}), \mathrm{H}_{0 \mathrm{E}}(\mathbf{b})\right.$, and $\left.\mathrm{L}(\mathbf{c})\right)$ are approximated by a regression; for the shape-related parameter ( $\left.\alpha_{\text {equ }}(\mathbf{d})\right)$, the mean value $(\mu)$ is calculated. The shading indicates the symmetric belts of two standard deviations $( \pm 1 \sigma)$ around the mean value $(\mu)$; the latter is very similar to the "forced" regression (regression parameters in Table 3).

\subsection{Volume-to-Ratio Correlations}

The second of the two approaches designed for statistical analyses of the behavior of shape-related parameters consists of volume-to-ratio correlations. From plotting the respective distributions, ratios of dimension-related parameters are assumed to behave like shape-related parameters and can, therefore, be analyzed in a similar way-however, with more sophisticated filtering.

Here, the correlation variable on the $y$-axis is a ratio of two individual (dimension-related) parameters characterizing the rupture zone in 3D (Figure 4, Table 1); after adding a fifth filter (Table 2), sample sizes for the set "full" are still very high ranging from 146 to 176 (second column of Table 5).

In analogy to the argumentation in the previous subsection, reported areas (A) and their projections to the horizontal $\left(\mathrm{A}_{h}\right)$ are less profitable candidates for ratios. This is also the case for separate widths $\left(\mathrm{w}_{0}\right.$ to $\left.\mathrm{w}_{\mathrm{E}}\right)$ and depths $\left(\mathrm{d}_{0}\right.$ to $\left.\mathrm{d}_{\mathrm{E}}\right)$, as they would result in specific ratios that might not be of great use for application; here, it appeared to be more promising to use the newly defined averaged parameters mentioned in the previous subsection $\left(\mathrm{d}_{\mathrm{av} 5}, \mathrm{~d}_{\mathrm{av} 4}, \mathrm{~d}_{\mathrm{av} 3}, \mathrm{w}_{\mathrm{av} 5}\right.$, and $\left.\mathrm{w}_{\mathrm{av} 3}\right)$ to create meaningful ratios.

With respect to these viewpoints and the aim of not creating ratios within the same types of dimension-related parameters (i.e., between lengths, heights, widths, and depths respectively), and accounting for the difference between maximum (e.g., W) and average parameters (e.g., $\mathrm{w}_{\mathrm{av} 5}$ ), 24 significant ratios were identified (Table 5).

Assuming that ratios behave statistically in the same way as other shape-related parameters, they underwent the same procedure of averaging values in order to keep the overall analyses homogeneous and comparable. Again, ratios reveal themselves as constant, emphasizing the assumption of self-similar shapes of rupture zones throughout different ranges of the calculated volume $\left(V_{\text {equ }}\right)$. Similar concepts of self-similarity were proposed, e.g., by Guzzetti et al. [18], Malamud et al. [16], and Stark and Guzzetti [38] with respect to the entire landslide zone (Figure 1a-d).

The same strong argument for the representativeness of the mean value $(\mu)$ applies to the volume-to-ratio correlations presented here. Table 5 shows for the set "full" that the fractions of data lie with minor deviations within symmetric belts of two $( \pm 1 \sigma)$, four $( \pm 2 \sigma)$ and six $( \pm 3 \sigma)$ standard deviations around the mean value $(\mu)$ indicating normal distributions. Also, the other five tested sets (Table 2) reveal very similar tendencies with respect to the required fraction of data within the three symmetric belts; only in five cases, sigma interval thresholds were missed by more than $5 \%$. 
Examples for averaging values are shown in Figure 8a-d for the set "full" for the ratio of the height between the point 0 and the point $\mathrm{E}$ to the projected length $\left(\mathrm{H}_{0 \mathrm{E}} / \mathrm{L}_{\mathrm{h}}\right)$, the ratio of the average depth to the length along the slope $\left(\mathrm{d}_{\mathrm{av} 5} / \mathrm{L}\right)$, the ratio of the average width to the length along the slope $\left(\mathrm{w}_{\mathrm{av} 5} / \mathrm{L}\right)$, and the ratio of the average depth to the average width $\left(\mathrm{d}_{\mathrm{av} 5} / \mathrm{w}_{\mathrm{av} 5}\right)$.
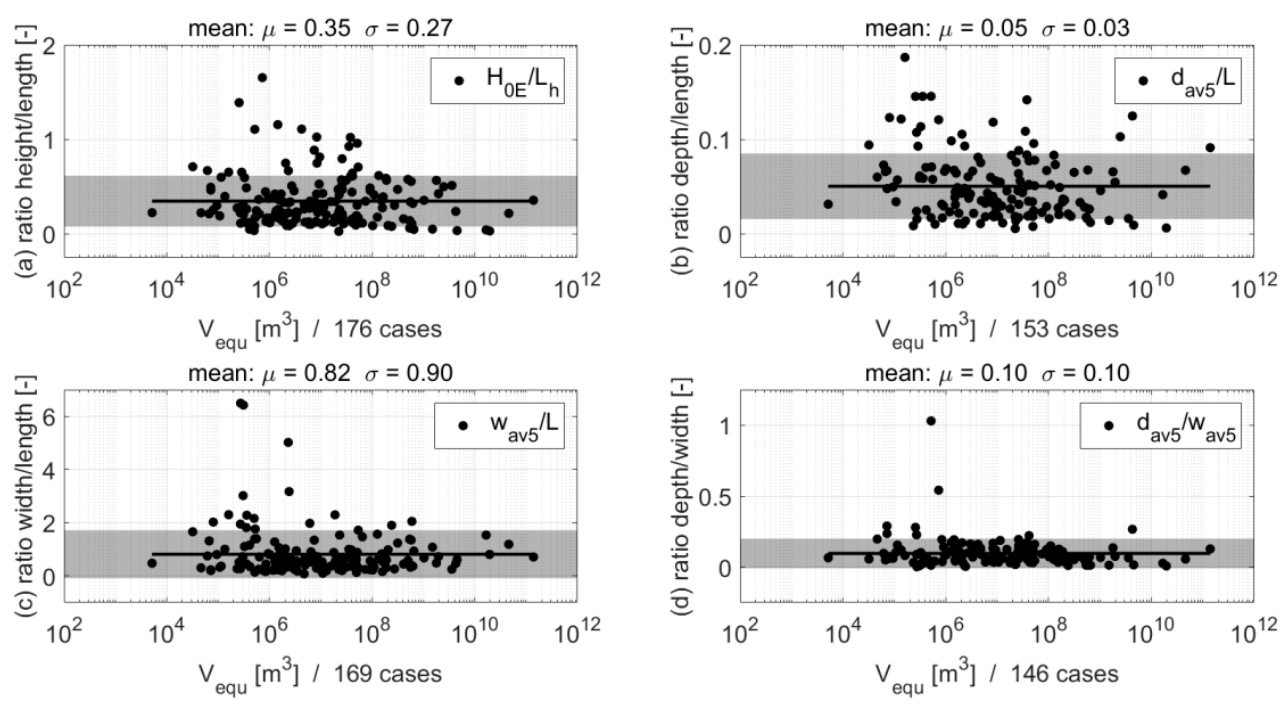

Figure 8. Examples of volume-to-ratio correlations for the set "full". For shape-related parameters (i.e., here the ratios; $\mathrm{H}_{0 \mathrm{E}} / \mathrm{L}_{\mathrm{h}}(\mathbf{a}), \mathrm{d}_{\mathrm{av} 5} / \mathrm{L}(\mathbf{b}), \mathrm{w}_{\mathrm{av} 5} / \mathrm{L}(\mathbf{c})$, and $\mathrm{d}_{\mathrm{av} 5} / \mathrm{w}_{\mathrm{av} 5}(\mathbf{d})$ ), the mean values $(\mu)$ are calculated. The shadings indicate the symmetric belts of two standard deviations $( \pm 1 \sigma)$ around the mean values $(\mu)$.

Comparing the four examples, the ratio of the average depth to the length along the slope $\left(\mathrm{d}_{\mathrm{av} 5} / \mathrm{L}\right)$ appears as the most dispersed (Figure $8 \mathrm{~b}$ ), although $75.8 \%$ of the data points lie still in symmetric belts of two $( \pm 1 \sigma)$ standard deviations around the mean value $(\mu)$. The dispersion reflects the fact that rupture zones of landslides appear to be unequal concerning depth, which is a strong argument of not using a simple multiplier when estimating depths of rupture zones and landslides in general.

The other three examples in Figure 8a-d also show good ratio stability throughout the calculated volumes $\left(\mathrm{V}_{\text {equ }}\right)$. This is particularly interesting for the ratio of the height between the point 0 and the point $\mathrm{E}$ to the projected length $\left(\mathrm{H}_{0 \mathrm{E}} / \mathrm{L}_{\mathrm{h}}\right)$, as Heim [39] reports a decreasing tendency for greater volumes - considering entire landslide zones, however. The argumentation is similar to the one for the suspicion of the slightly decreasing trend for the calculated slope angle $\left(\alpha_{\text {equ }}\right.$; Figure $\left.7 \mathrm{~d}\right)$ since it corresponds to the inverse tangent of the ratio of the height between the point 0 and the point $\mathrm{E}$ to the projected length $\left(\mathrm{H}_{0 \mathrm{E}} / \mathrm{L}_{\mathrm{h}}\right)$. This minimally (or not distinctly pronounced) decreasing tendency could be due to the focus on the rupture zone only.

All mean values $(\mu)$ are listed in Table 5 together with their standard deviations $(\sigma)$ and the relations between both types of values $(\mu / \sigma)$ as a measure for dispersion.

In contrast to Figure 7a-d, the semi-logarithmic diagrams in Figure 8a-d attest differently dispersed data. Here, the following questions arise: (i) Should extreme outliers, such as in the diagram of the ratio of the average width to the length along the slope ( $w_{\mathrm{av} 5} / \mathrm{L}$; Figure $\left.8 \mathrm{c}\right)$, be discarded from the analyses? (ii) Is the median more representative compared to the mean value $(\mu)$ ? To answer the first question, it can be argued that the highest points in the data cloud are generated by extremely wide but short rupture zones. To exclude them would require them to be discarded from the entirety of the statistical analyses to ensure consistent datasets. This, however, is wrong, since those landslides are not necessarily responsible for outliers in other diagrams; i.e., the same landslides might present a normal ratio of the height between point 0 and point $\mathrm{E}$ to the maximum depth $\left(\mathrm{H}_{0 \mathrm{E}} / \mathrm{D}\right)$. Hence, datasets cannot be individually curtailed. 
Concerning the median, it can be shown via several tests that mean values $(\mu)$ and medians are usually very similar; therefore, both appear to be justifiable representatives. Due to the close link between the standard deviation $(\sigma)$ and the mean value $(\mu)$, the latter seems more practical, however.

\section{Discussion of Results of All Six Sets}

In contrast to the previous two subsections in which the analytical procedures and results were discussed with particular focus on the set "full", the discussion is dedicated to the comparison of results of all six tested sets (Table 2).

In the first stage, it might be of interest how similar regressions for individual parameters per set are to each other. This question, indeed, concerns only dimension-related parameters whose values increase with greater calculated volumes ( $\mathrm{V}_{\text {equ }}$; Table 3 ). To allow for easy comparison, regressions (Equation (2)) for each dimension-related parameter per set are represented in a separate double-logarithmic diagram (colored lines in Figure 9a-d). Based on the averages of the six constants (a) and the six factors (b) of the individual sets, average constants (a) and factors (b) that define these regressions are to be found in Table 6a (dashed black line in Figure 9a-d).
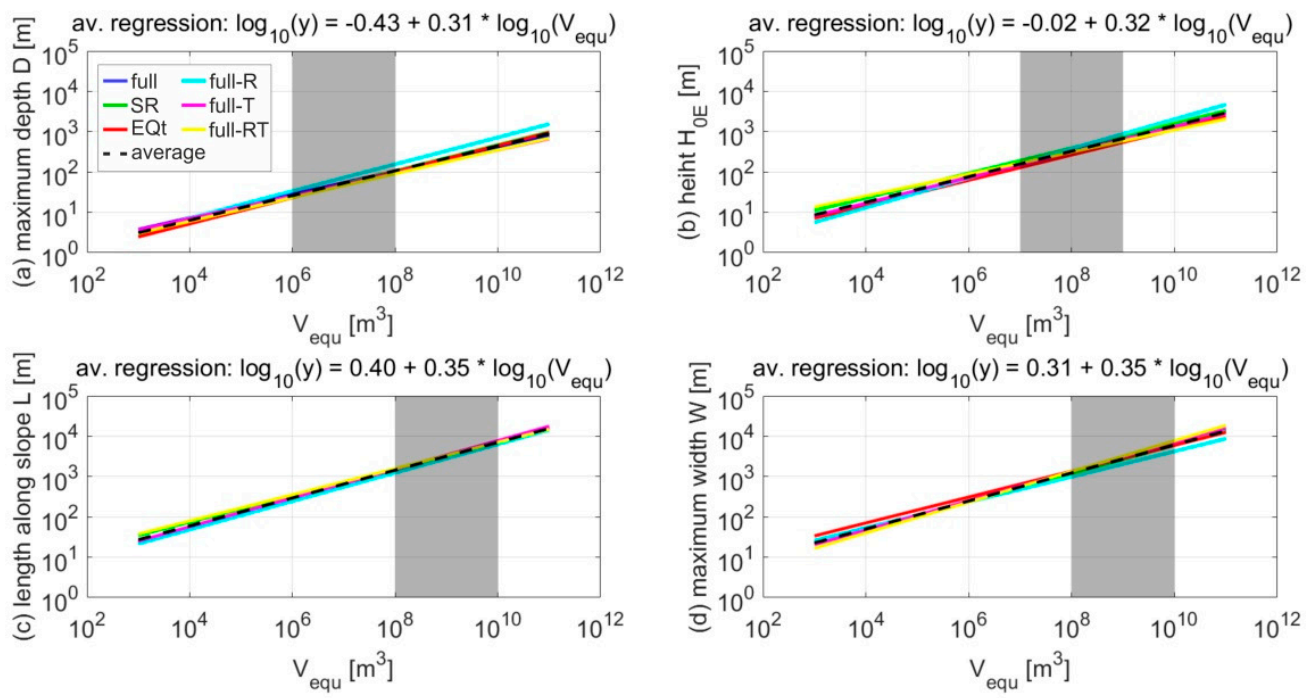

Figure 9. Comparison of regressions ( $\mathrm{D}(\mathbf{a}), \mathrm{H}_{0 \mathrm{E}}(\mathbf{b}), \mathrm{L}(\mathbf{c})$, and $\left.\mathrm{W}(\mathbf{d})\right)$ of the six tested sets and the respective average regression, as shown in Table $6 \mathrm{a}$. The shadings indicate the visually derived zones of maximum overlap.

Exemplarily, Figure 9a-d shows such regression comparisons for the maximum depth (D), the height between the point 0 and the point $\mathrm{E}\left(\mathrm{H}_{0 \mathrm{E}}\right)$, the length along the slope $(\mathrm{L})$, and the maximum width $(\mathrm{W})$ in order to display one representative of each type of dimension-related parameters (i.e., depths, heights, lengths, and widths). The diagrams reveal that the regressions are consistent comparing different sets due to very similar constants (a) and factors (b); the average regressions, thus, appear to be reliable representatives.

Comparing these regressions per type of dimension-related parameters (i.e., depths, heights, lengths, and widths), it can be shown that-independently of the initial calculated volume $\left(\mathrm{V}_{\text {equ }}\right.$ - - volume and parameters increase by different factors. Over a volume range that increases with factors following a power series based on 10 (i.e., $10^{\mathrm{k}-1}$ ), the other parameter types experience increases by factors that follow more or less a power series based on 2 (i.e., $2.05^{\mathrm{k}-1}$ to $2.23^{\mathrm{k}-1}$ ), which becomes visible as straight regression lines with slightly different gradients in double-logarithmic diagrams (Figure $9 \mathrm{a}-\mathrm{d}$ ) as power-law distributions are scale-invariant.

Moreover, juxtapositions of the diagrams (Figure 9a-d) reveal that the regression parameters (i.e., constants (a) and factors (b); Equation (2)) of depths are generally smaller than those of the heights 
and that the regression parameters of heights are smaller than those of the lengths and widths. Usually, landslide rupture zones are much higher than deep (Figure 4). Also, the fact that lengths exceed heights seems logical, as in the opposite case, the described setting would be rather atypical for landslides and resemble, e.g., toppling or even rock fall. The interesting detail within these magnitude comparisons is that, on closer inspection, regressions of lengths and widths are particularly similar, suggesting that landslide rupture zones are on average as wide as long in terms of orders of magnitude. Furthermore, ratios relating widths and lengths $\left(\mathrm{W} / \mathrm{L}, \mathrm{w}_{\mathrm{av} 5} / \mathrm{L}\right.$, and $\mathrm{w}_{\mathrm{av} 3} / \mathrm{L}$; Tables 5 and $\left.6 \mathrm{c}\right)$ show values varying around 1. This latter fact might have been overlooked as publications strive rather for the accurate assessment of LCS than for TCS [40]. One of the reasons for this preferential focus could be the so-far predominant limitation of numerical landslide models to 2D. With the recent approaches of landslide modeling in 3D, their lateral extent becomes indispensable, and thus, the roundness or ellipticity defined by lengths and widths of a rupture zone might add relevant information.

Table 6. Average results for the volume-to-parameter correlations (a, b) and for the volume-to-ratio correlations (c). For all dimension-related parameters (a), the average regression parameters (constant (a) and factor (b); Equation (2)) are given; for all shape-related parameters (b, c), the table shows the average mean values $(\mu)$ with the respective average standard deviations $(\sigma)$. As $d_{0}$ contains 0 and $d_{E}$ is always 0 , they are not fitted in a double-logarithmic diagram.

\begin{tabular}{|c|c|c|c|c|c|}
\hline $\begin{array}{c}\text { (a) } \\
\mathrm{V}_{\text {equ }} /\end{array}$ & $\begin{array}{c}\text { Average } \\
\text { Regression } \\
\text { Parameters } \\
\text { (co. (a) | fa. (b)) }\end{array}$ & $\begin{array}{c}\text { (b) } \\
\mathrm{V}_{\text {equ }} /\end{array}$ & $\begin{array}{c}\text { Average } \\
\text { Horizontal } \\
\text { Reference Line } \\
(\mu \mid \sigma)\end{array}$ & $\begin{array}{c}\text { (c) } \\
V_{\text {equ }} /\end{array}$ & $\begin{array}{c}\text { Average } \\
\text { Horizontal } \\
\text { Reference Line } \\
(\mu \mid \sigma)\end{array}$ \\
\hline $\mathrm{D}$ & $-0.43 \mid 0.31$ & $\delta_{0}$ & $50.15 \mid 19.65$ & $\mathrm{H}_{0 \mathrm{E}} / \mathrm{L}_{\mathrm{h}}$ & $0.35 \mid 0.28$ \\
\hline $\mathrm{d}_{\mathrm{av} 5}$ & $-0.71 \mid 0.30$ & $\delta_{1}$ & 18.65 13.85 & $\mathrm{H}_{\max } / \mathrm{L}_{\mathrm{h}}$ & $0.36 \mid 0.27$ \\
\hline $\mathrm{d}_{\mathrm{av} 4}$ & $-0.61 \mid 0.30$ & $\delta_{2}$ & $15.15 \mid 14.07$ & $\mathrm{H}_{0 \mathrm{E}} / \mathrm{W}$ & $0.49 \mid 0.51$ \\
\hline $\mathrm{d}_{\mathrm{av} 3}$ & $-0.52 \mid 0.31$ & $\delta_{3}$ & $10.86 \mid 11.62$ & $\mathrm{H}_{0 \mathrm{E}} / \mathrm{w}_{\mathrm{av} 5}$ & $0.71 \mid 0.75$ \\
\hline $\mathrm{d}_{0}$ & - & $\delta_{\mathrm{E}}$ & $-0.27 \mid 16.84$ & $\mathrm{H}_{0 \mathrm{E}} / \mathrm{w}_{\mathrm{av} 3}$ & $0.61 \mid 0.67$ \\
\hline $\mathrm{d}_{1}$ & $-0.49 \mid 0.31$ & cur & $50.42 \mid 25.11$ & $\mathrm{H}_{0 \mathrm{E}} / \mathrm{D}$ & $3.99 \mid 3.25$ \\
\hline $\mathrm{d}_{2}$ & $-0.44 \mid 0.30$ & $\alpha_{\text {equ }}$ & $18.10 \mid 12.01$ & $\mathrm{H}_{0 \mathrm{E}} / \mathrm{d}_{\mathrm{av} 5}$ & $7.90 \mid 5.82$ \\
\hline$d_{3}$ & $-0.69 \mid 0.31$ & $\alpha_{\text {lit }}$ & $20.75 \mid 12.86$ & $\mathrm{H}_{0 \mathrm{E}} / \mathrm{d}_{\mathrm{av} 4}$ & $6.32 \mid 4.65$ \\
\hline $\mathrm{d}_{\mathrm{E}}$ & - & & & $\mathrm{H}_{0 \mathrm{E}} / \mathrm{d}_{\mathrm{av} 3}$ & $4.91 \mid 3.58$ \\
\hline $\mathrm{H}_{0 \mathrm{E}}$ & $-0.02 \mid 0.32$ & & & $\mathrm{D} / \mathrm{L}$ & $0.10 \mid 0.07$ \\
\hline $\mathrm{H}_{\max }$ & $-0.02 \mid 0.32$ & & & $\mathrm{~d}_{\mathrm{av} 5} / \mathrm{L}$ & $0.05 \mid 0.03$ \\
\hline $\mathrm{L}$ & $0.40 \mid 0.35$ & & & $\mathrm{~d}_{\mathrm{av} 4} / \mathrm{L}$ & $0.06 \mid 0.04$ \\
\hline $\mathrm{L}_{\mathrm{h}}$ & $0.34 \mid 0.35$ & & & $\mathrm{~d}_{\mathrm{av} 3 / \mathrm{L}}$ & $0.08 \mid 0.05$ \\
\hline W & $0.31 \mid 0.35$ & & & $\mathrm{~W} / \mathrm{L}$ & $1.22 \mid 1.47$ \\
\hline $\mathrm{w}_{\text {av5 }}$ & $0.18 \mid 0.34$ & & & $\mathrm{w}_{\mathrm{av} 5} / \mathrm{L}$ & $0.84 \mid 0.89$ \\
\hline $\mathrm{w}_{\mathrm{av} 3}$ & $0.27 \mid 0.34$ & & & $\mathrm{w}_{\mathrm{av} 3} / \mathrm{L}$ & $0.97 \mid 1.00$ \\
\hline $\mathrm{w}_{0}$ & $0.00 \mid 0.32$ & & & $\mathrm{D} / \mathrm{W}$ & $0.14 \mid 0.12$ \\
\hline $\mathrm{w}_{1}$ & $0.25 \mid 0.34$ & & & $\mathrm{D} / \mathrm{w}_{\mathrm{av} 5}$ & $0.19 \mid 0.16$ \\
\hline $\mathrm{w}_{2}$ & $0.28 \mid 0.34$ & & & $\mathrm{D} / \mathrm{w}_{\mathrm{av} 3}$ & $0.16 \mid 0.14$ \\
\hline$w_{3}$ & $0.25 \mid 0.34$ & & & $\mathrm{~d}_{\mathrm{av} 5} / \mathrm{W}$ & $0.07 \mid 0.07$ \\
\hline \multirow[t]{4}{*}{$w_{E}$} & $0.03 \mid 0.35$ & & & $\mathrm{~d}_{\mathrm{av} 4} / \mathrm{W}$ & $0.09 \mid 0.09$ \\
\hline & & & & $\mathrm{d}_{\mathrm{av} 3} / \mathrm{W}$ & $0.11 \mid 0.12$ \\
\hline & & & & $\mathrm{d}_{\mathrm{av} 5} / \mathrm{w}_{\mathrm{av} 5}$ & $0.09 \mid 0.10$ \\
\hline & & & & $\mathrm{d}_{\mathrm{av} 3} / \mathrm{w}_{\mathrm{av} 3}$ & $0.13 \mid 0.14$ \\
\hline
\end{tabular}

Another feature (although visually subjective) is the zone of maximum overlap of the regressions of the six sets and the average regression (Figure $9 a-d)$. For depth parameters $\left(D, d_{1}, d_{2}, d_{3}, d_{a v 5}\right.$, $\mathrm{d}_{\mathrm{av} 4}$, and $\mathrm{d}_{\mathrm{av} 3}$ ) the regression overlap occurs between $10^{6} \mathrm{~m}^{3}$ and $10^{8} \mathrm{~m}^{3}$ of the calculated volume $\left(\mathrm{V}_{\text {equ }}\right)$, for height parameters $\left(\mathrm{H}_{0 \mathrm{E}}\right.$ and $\left.\mathrm{H}_{\mathrm{max}}\right)$ between $10^{7} \mathrm{~m}^{3}$ and $10^{9} \mathrm{~m}^{3}$, and for length and width parameters $\left(\mathrm{L}, \mathrm{L}_{\mathrm{h}}, \mathrm{W}, \mathrm{w}_{0}, \mathrm{w}_{1}, \mathrm{w}_{2}, \mathrm{w}_{3}, \mathrm{w}_{\mathrm{E}}, \mathrm{w}_{\mathrm{av}}\right.$, and $\left.\mathrm{w}_{\mathrm{av} 3}\right)$ between $10^{8} \mathrm{~m}^{3}$ and $10^{10} \mathrm{~m}^{3}$. Thus, it seems, that regressions of parameters with generally higher values tend to overlap better at higher ranges of the calculated volume $\left(\mathrm{V}_{\text {equ }}\right)$ and vice versa.

In a second stage, it is of particular interest how similar mean values $(\mu)$ of individual shape-related parameters are throughout the six sets. Here, this question targets the analyses of the angles at the points 0 to $\mathrm{E}\left(\delta_{0}\right.$ to $\left.\delta_{\mathrm{E}}\right)$, the curvature (cur) and the slope angles ( $\alpha_{\text {equ }}$ and $\left.\alpha_{\text {lit }}\right)$ as well as the analyses 
of all ratios (Tables 4 and 5). As they are constant over the entire range of the calculated volume $\left(V_{\text {equ }}\right)$ showing similar values throughout the six tested sets (Table 2), the choice of the averages of the six mean values $(\mu)$ is a very legitimate representative value for each of the shape-related parameters (Table $6 \mathrm{~b}, \mathrm{c}$ ). Expected shapes of landslide rupture zones based on these average ratios of dimension-related parameters are shown in Figure 10.

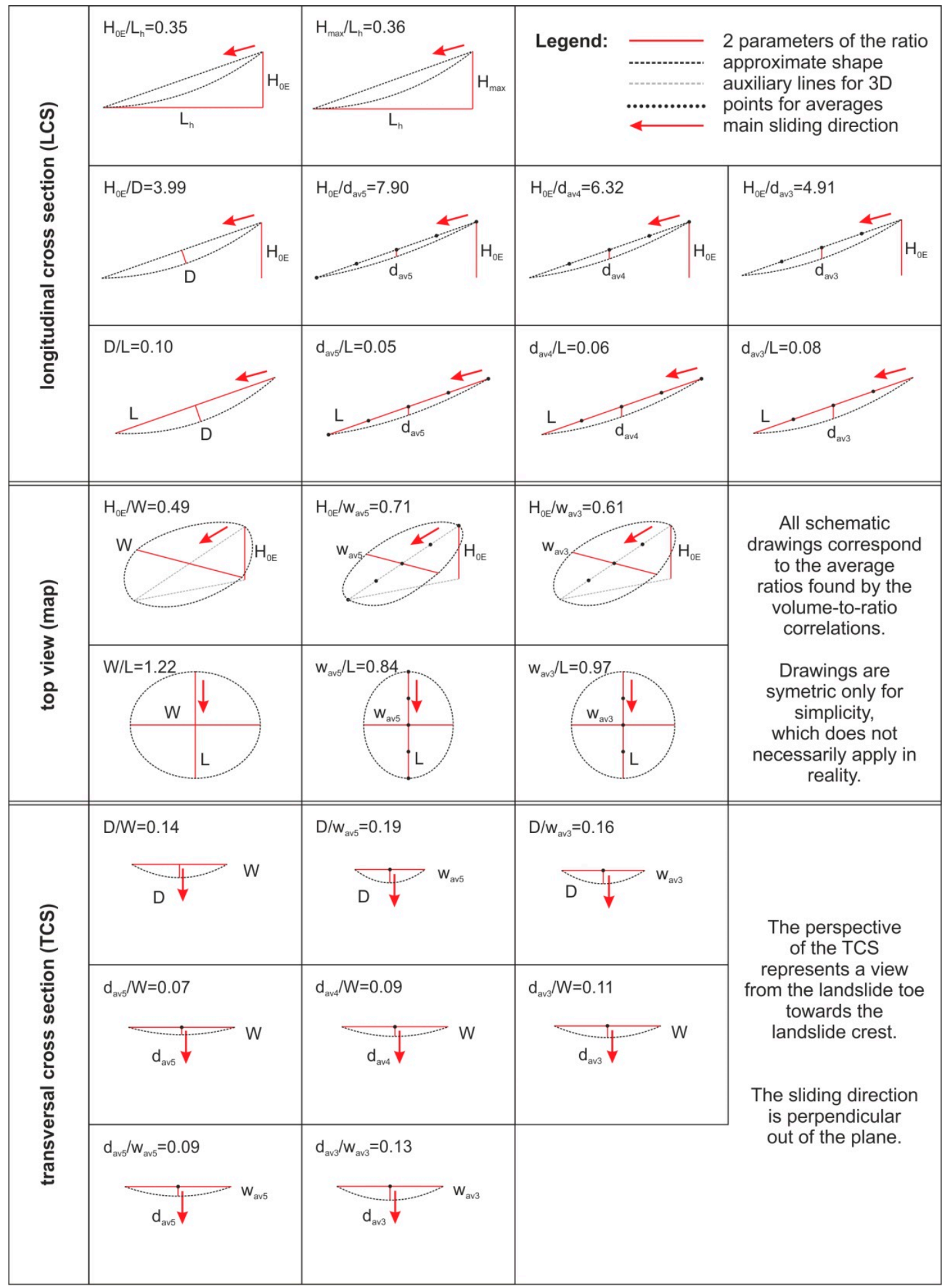

Figure 10. Schematic representation of ratios of dimension-related parameters. All schematic drawings correspond to the average ratios found by the volume-to-ratio-correlation shown in Table 6c. 
In Domej et al. [31], the ratio of the height between the point 0 and the point $E$ to the projected length $\left(\mathrm{H}_{0 \mathrm{E}} / \mathrm{L}_{\mathrm{h}}\right)$, the ratio of the average depth to the length along the slope $\left(\mathrm{d}_{\mathrm{av} 5} / \mathrm{L}\right)$, the ratio of the average width to the projected length along the slope $\left(\mathrm{w}_{\mathrm{av} 5} / \mathrm{L}_{\mathrm{h}}\right)$, and the ratio of the average depth to the average width $\left(\mathrm{d}_{\mathrm{av} 5} / \mathrm{w}_{\mathrm{av}}\right)$ were evaluated for three sets ("full", "SR", and "EQt") via a grouping approach according to three volume classes $\left(10^{3}-10^{6} \mathrm{~m}^{3}, 10^{6}-10^{9} \mathrm{~m}^{3}\right.$ and $\left.10^{9}-10^{12} \mathrm{~m}^{3}\right)$. The hereby obtained ratios (Figure 11a-d, Table 7) match well with those of the analyses presented here.
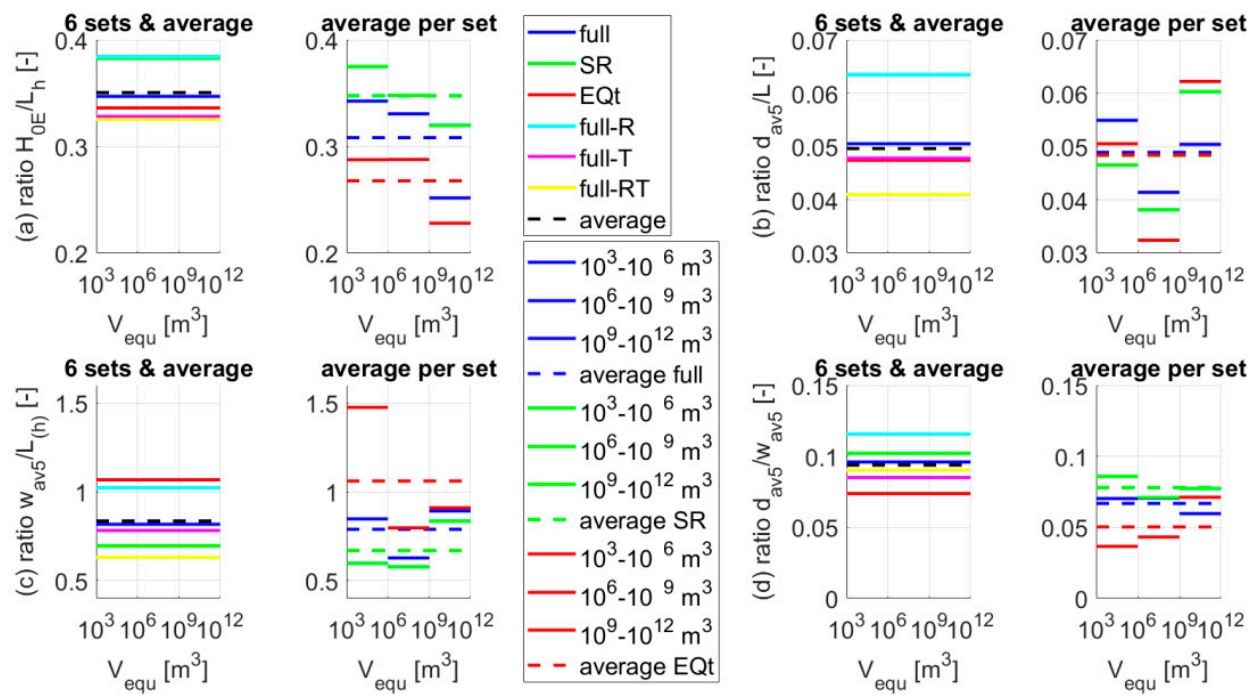

Figure 11. Comparison $\left(\mathrm{H}_{0 \mathrm{E}} / \mathrm{L}_{\mathrm{h}}(\mathbf{a}), \mathrm{d}_{\mathrm{av} 5} / \mathrm{L}(\mathbf{b}), \mathrm{w}_{\mathrm{av} 5} / \mathrm{L}_{(\mathrm{h})}(\mathbf{c})\right.$, and $\left.\mathrm{d}_{\mathrm{av} 5} / \mathrm{w}_{\mathrm{av} 5}(\mathbf{d})\right)$ of mean values of ratios $(\mu)$ for the six tested sets and the respective average mean value $(\mu)$ of this publication (Tables 5 and $6 c$; left subplots) and of the average of the mean values $(\mu)$ per set as presented in Domej et al. [31] (Table 7; right subplots).

Table 7. Ratios per volume group as reported in Domej et al. [31]. The value triplets correspond to the ratios per tested set ("full" ( $\left.{ }^{a}\right)$, "SR" $\left({ }^{b}\right)$, and "EQt" $\left({ }^{c}\right)$ ).

\begin{tabular}{|c|c|c|c|c|}
\hline Ratios in Domej et al. [31] & Group $10^{3}-10^{6} \mathrm{~m}^{3}$ & Group $10^{6}-10^{9} \mathrm{~m}^{3}$ & Group $10^{9}-10^{12} \mathrm{~m}^{3}$ & Average per Set \\
\hline \multirow{3}{*}{$\mathrm{H}_{0 \mathrm{E}} / \mathrm{L}_{\mathrm{h}}$} & $0.34^{\mathrm{a}}$ & $0.33^{a}$ & $0.25^{\mathrm{a}}$ & $0.31^{\mathrm{a}}$ \\
\hline & $0.38^{b}$ & $0.35^{b}$ & $0.32^{b}$ & $0.35^{\mathrm{b}}$ \\
\hline & $0.29^{c}$ & $0.29^{c}$ & $0.23^{c}$ & $0.27^{\mathrm{c}}$ \\
\hline \multirow{3}{*}{$\mathrm{d}_{\mathrm{av} 5 / \mathrm{L}}$} & $0.05^{\mathrm{a}}$ & $0.04^{a}$ & $0.05^{\mathrm{a}}$ & $0.05^{\mathrm{a}}$ \\
\hline & $0.05^{b}$ & $0.04^{b}$ & $0.06^{b}$ & $0.05^{b}$ \\
\hline & $0.05^{\mathrm{c}}$ & $0.03^{c}$ & $0.06^{\mathrm{c}}$ & $0.05^{\mathrm{c}}$ \\
\hline \multirow{3}{*}{$\mathrm{w}_{\mathrm{av} 5} / \mathrm{L}_{\mathrm{h}}$} & $0.85^{\mathrm{a}}$ & $0.63^{a}$ & $0.89^{a}$ & $0.79^{\mathrm{a}}$ \\
\hline & $0.60^{b}$ & $0.58^{\mathrm{b}}$ & $0.83^{b}$ & $0.67^{b}$ \\
\hline & $1.48^{\mathrm{c}}$ & $0.80^{c}$ & $0.91^{\mathrm{c}}$ & $1.06^{c}$ \\
\hline \multirow{3}{*}{$\mathrm{d}_{\mathrm{av} 5} / \mathrm{w}_{\mathrm{av}}$} & $0.07^{\mathrm{a}}$ & $0.07^{\mathrm{a}}$ & $0.06^{\mathrm{a}}$ & $0.07^{\mathrm{a}}$ \\
\hline & $0.09^{b}$ & $0.07^{b}$ & $0.08^{b}$ & $0.08^{b}$ \\
\hline & $0.04^{\mathrm{c}}$ & $0.04^{\mathrm{c}}$ & $0.07^{\mathrm{c}}$ & $0.05^{\mathrm{c}}$ \\
\hline
\end{tabular}

\section{Conclusions and Perspectives}

In this work, the newly built, chronologic and global landslide database presented by Domej et al. [31] was revisited with the aim of a detailed exploration of the statistical behavior of dimension- and shape-related parameters characterizing a landslide rupture zone in 3D (Figure 4, Table 1), while the majority of available studies focusses on the entire landslide zone (e.g., [16-23]). For six different sets (Table 2) that were filtered from the landslide database, the analyses are based on volume-to-parameter correlations of all exploitable dimension-related parameters (i.e., depths, heights, lengths, and widths; Table 3 ) and the eight shape-related parameters (i.e., angles at the points 0 to $\mathrm{E}\left(\delta_{0}\right.$ to $\delta_{\mathrm{E}}$ ), curvature (cur), and reported and calculated slope angle ( $\alpha_{\text {equ }}$ and $\alpha_{\text {lit }}$ ); Table 4 ) as well as on volume-to-ratio correlations of all ratios of dimension-related parameters (Table 5). 
Independently on the six tested sets (Table 2) characterized by different global distributions, materials, and triggering mechanisms, both types of analyses revealed a significant difference in the statistical behaviors of these two types of parameters. All dimension-related parameters showed a clear scale-invariant increase with greater calculated volumes $\left(V_{\text {equ}}\right.$; Figure $\left.7 \mathrm{a}-\mathrm{c}\right)$, whereas all shape-related parameters and the ratios of dimension-related parameters remained constant throughout the full range of calculated volumes ( $\mathrm{V}_{\text {equ }}$; Figures $7 \mathrm{~d}$ and $\left.8 \mathrm{a}-\mathrm{d}\right)$.

Results are consistent with preliminary analyses of the authors [31] but show a higher degree of detail, allowing for a broader spectrum of use.

Since regressions for dimension-related parameters are very similar (Figure 9a-d, Tables 3 and 6a), one could use the average regression of a distinct parameter to extrapolate from a given value to the calculated volume $\left(\mathrm{V}_{\text {equ }}\right)$ of a rupture zone (Figure 6). This potential field of application might be of interest for preliminary assessments of rupture zone dimensions, e.g., during fieldwork or rapid first stage inventories anticipating exact geological, geotechnical, and geophysical surveys. Depending on the desired accuracy, one might consider the average regressions per respective dimension-related parameter, or one of the set specific regressions can be used if the considered landslide is known to match one of the filters (Table 2).

As for the shape-related parameters, the analyses also deliver very satisfactory results compared to those of Domej et al. [31], with those ratios existing in both publications being almost identical (Figure 11a-d, Tables 5, 6c and 7). This work offers, however, a much wider range of possible applications since all eight shape-related parameters and many more ratio combinations were considered. On the one hand, one might benefit here from the finding that the eight shape-related parameters (i.e., angles at the points 0 to $\mathrm{E}\left(\delta_{0}\right.$ to $\left.\delta_{\mathrm{E}}\right)$, curvature (cur), and reported and calculated slope angle $\left(\alpha_{\mathrm{equ}}\right.$ and $\left.\alpha_{\text {lit }}\right)$; Tables 4 and 6 b) are stable throughout all volume ranges a fact that speaks for self-similar shapes of rupture zones (Figure 10), and also finds its application during preliminary assessments of rupture zone dimensions. On the other hand, one might make use of the constancy of ratios of dimension-related parameters (Tables 5 and $6 \mathrm{c}$ ) by deducing one of the two parameters when the other one is given (Figure 6). This latter aspect seems to be particularly promising for remote sensing surveys when initial rupture areas or rupture volumes should be delineated. Very often, remote sensing allows for mapping of entire landslide areas that are affected by sliding processes (Figure $1 \mathrm{a}-\mathrm{d}$ ). Here, it could remain unclear where the rupture zone ends due to overlaps or even offsets of landslide deposits. If dimension-related parameters relating to horizontal and/or vertical expansion are known in such cases, and if one relies on constant ratios between them, it could be possible to trace back the rupture areas and/or the rupture volumes of landslides.

Moreover, for numerical modeling of landslides, the volume-to-ratio correlations could be of particular interest. Correlations of depth and length of rupture zones shown in Figure $8 \mathrm{~b}$ reveal a more significant dispersion compared to other correlations-i.e., depths appear to be highly variable. It might be, therefore, interesting to make use of the here presented depth correlations at different points (Figure 4) when creating 2D or 3D models, instead of using multipliers to estimate depths.

As a final remark on perspectives, it should be mentioned that, although the entire statistical analyses were carried out based on the calculated volume $\left(V_{\text {equ }}\right)$ as first variable of correlation for the volume-to-parameter correlations as well as for the volume-to-ratio correlations, it is possible to filter data with respect to different variables of correlation at any moment. Therefore, an almost countless number of options to retrieve and analyze data from the landslide database exists. According to different needs and demands, filters can be customized, and it is likewise possible to create new parameters or ratios from the existing dimension- and/or shape-related parameters.

Author Contributions: The research work (conceptualization, methodology, formal analysis, data curation, writing-original draft preparation, writing-review and editing, visualization) was completed by the main author, G.D. The three co-authors C.B., L.L., and S.M. supervised the interpretation of the results. The manuscript was prepared in close collaboration between G.D. and C.B. and was corrected by the two other co-authors. K.P. provided technical assistance during the import of the assessed landslide data into the database. All authors have read and agree to the published version of the manuscript. 
Funding: This research received no external funding.

Data Sources: Data included in the database does not belong to the authors of this publication. The following references do not include publications associated with the individual landslides in the database. However, it is possible to provide (on demand) a full list of evaluated literature for every case, since the database is-for the time being-not publicly available.

Conflicts of Interest: The authors declare no conflict of interest.

\section{Appendix A}

Table A1. Landslides included in the database. Columns from left to right give respectively the identification number in the database, the date of the major failure or the time since when sliding is reported (for active landsides), the name and country codes after ISO 3166-1 alpha-2 [41], the location as latitude and longitude, and the trigger if known (EQ referring to "earthquake", GW referring to "groundwater").

\begin{tabular}{|c|c|c|c|c|c|c|}
\hline No. & Date & Landslide & C. & Latitude & Longitude & Trigger \\
\hline 001.00 & 2001-03-18 & Diezma & ES & $37^{\circ} 18^{\prime} 34.00^{\prime \prime} \mathrm{N}$ & $003^{\circ} 22^{\prime} 08.70^{\prime \prime} \mathrm{W}$ & rain \\
\hline 002.00 & 1949-07-10 & Khait & $\mathrm{TJ}$ & $39^{\circ} 11^{\prime} 27.40^{\prime \prime} \mathrm{N}$ & $070^{\circ} 55^{\prime} 41.20^{\prime \prime} \mathrm{E}$ & Khait EQ \\
\hline 003.01 & paleo & Leupegem Hill 1 & $\mathrm{BE}$ & $50^{\circ} 49^{\prime} 25.07^{\prime \prime} \mathrm{N}$ & $003^{\circ} 37^{\prime} 18.62^{\prime \prime} \mathrm{E}$ & - \\
\hline 003.02 & paleo & Leupegem Hill 2 & $\mathrm{BE}$ & $50^{\circ} 49^{\prime} 33.10^{\prime \prime} \mathrm{N}$ & $003^{\circ} 37^{\prime} 15.99^{\prime \prime} \mathrm{E}$ & - \\
\hline 003.03 & paleo & Leupegem Hill 3 & $\mathrm{BE}$ & $50^{\circ} 49^{\prime} 36.13^{\prime \prime} \mathrm{N}$ & $003^{\circ} 37^{\prime} 10.17^{\prime \prime} \mathrm{E}$ & - \\
\hline 003.04 & paleo & Rotelenberg Hill 4 & $\mathrm{BE}$ & $50^{\circ} 48^{\prime} 32.35^{\prime \prime} \mathrm{N}$ & $003^{\circ} 34^{\prime} 50.33^{\prime \prime} \mathrm{E}$ & - \\
\hline 003.05 & paleo & Rotelenberg Hill 5 & $\mathrm{BE}$ & $50^{\circ} 48^{\prime} 37.41^{\prime \prime} \mathrm{N}$ & $003^{\circ} 34^{\prime} 36.52^{\prime \prime} \mathrm{E}$ & - \\
\hline 003.06 & paleo & Rotelenberg Hill 6 & $\mathrm{BE}$ & $50^{\circ} 48^{\prime} 43.61^{\prime \prime} \mathrm{N}$ & $003^{\circ} 34^{\prime} 36.17^{\prime \prime} \mathrm{E}$ & - \\
\hline 003.07 & paleo & Rotelenberg Hill 7 & $\mathrm{BE}$ & $50^{\circ} 48^{\prime} 45.25^{\prime \prime} \mathrm{N}$ & $003^{\circ} 34^{\prime} 44.67^{\prime \prime} \mathrm{E}$ & - \\
\hline 003.08 & paleo & Rotelenberg Hill 8 & $\mathrm{BE}$ & $50^{\circ} 48^{\prime} 48.53^{\prime \prime} \mathrm{N}$ & $003^{\circ} 34^{\prime} 52.19^{\prime \prime} \mathrm{E}$ & - \\
\hline 003.09 & paleo & Rotelenberg Hill 9 & $\mathrm{BE}$ & $50^{\circ} 48^{\prime} 47.08^{\prime \prime} \mathrm{N}$ & $003^{\circ} 35^{\prime} 00.05^{\prime \prime} \mathrm{E}$ & - \\
\hline 003.10 & paleo & Rotelenberg Hill 10 & $\mathrm{BE}$ & $50^{\circ} 48^{\prime} 45.23^{\prime \prime} \mathrm{N}$ & $003^{\circ} 35^{\prime} 09.95^{\prime \prime} \mathrm{E}$ & - \\
\hline 003.11 & paleo & Rotelenberg Hill 11 & $\mathrm{BE}$ & $50^{\circ} 48^{\prime} 43.86^{\prime \prime} \mathrm{N}$ & $003^{\circ} 35^{\prime} 17.67^{\prime \prime} \mathrm{E}$ & - \\
\hline 003.12 & paleo & Rotelenberg Hill 12 & $\mathrm{BE}$ & $50^{\circ} 48^{\prime} 48.64^{\prime \prime} \mathrm{N}$ & $003^{\circ} 35^{\prime} 25.54^{\prime \prime} \mathrm{E}$ & - \\
\hline 003.13 & paleo & Rotelenberg Hill 13 & $\mathrm{BE}$ & $50^{\circ} 48^{\prime} 53.55^{\prime \prime} \mathrm{N}$ & $003^{\circ} 35^{\prime} 27.93^{\prime \prime} \mathrm{E}$ & - \\
\hline 004.00 & $?$ & Büyükçekmece & TR & $41^{\circ} 00^{\prime} 34.67^{\prime \prime} \mathrm{N}$ & $028^{\circ} 37^{\prime} 02.45^{\prime \prime} \mathrm{E}$ & overload \\
\hline 005.01 & 2008-05-12 & Chengxi & $\mathrm{CN}$ & $31^{\circ} 49^{\prime} 33.01^{\prime \prime} \mathrm{N}$ & $104^{\circ} 26^{\prime} 57.36^{\prime \prime} \mathrm{E}$ & Sichuan EQ \\
\hline 005.02 & 2008-05-12 & Xinbei Middle-School & $\mathrm{CN}$ & $31^{\circ} 49^{\prime} 46.43^{\prime \prime} \mathrm{N}$ & $104^{\circ} 27^{\prime} 36.25^{\prime \prime} \mathrm{E}$ & Sichuan EQ \\
\hline 005.03 & 2008-05-12 & Tangjiashan & $\mathrm{CN}$ & $31^{\circ} 50^{\prime} 25.30^{\prime \prime} \mathrm{N}$ & $104^{\circ} 25^{\prime} 59.14^{\prime \prime} \mathrm{E}$ & Sichuan EQ \\
\hline 005.04 & 2008-05-12 & Daguangbao & $\mathrm{CN}$ & $31^{\circ} 38^{\prime} 30.91^{\prime \prime} \mathrm{N}$ & $104^{\circ} 06^{\prime} 50.34^{\prime \prime} \mathrm{E}$ & Sichuan EQ \\
\hline 006.00 & $?$ & Lushan Hot Spring & TW & $24^{\circ} 01^{\prime} 32.23^{\prime \prime} \mathrm{N}$ & $121^{\circ} 11^{\prime} 02.25^{\prime \prime} \mathrm{E}$ & storm \\
\hline 007.01 & 1969 & Ain El Hammam & $\mathrm{DZ}$ & $36^{\circ} 34^{\prime} 15.18^{\prime \prime} \mathrm{N}$ & $004^{\circ} 18^{\prime} 12.23^{\prime \prime} \mathrm{E}$ & - \\
\hline 007.02 & 1970 & Tigzirt City & $\mathrm{DZ}$ & $36^{\circ} 53^{\prime} 10.39^{\prime \prime} \mathrm{N}$ & $004^{\circ} 08^{\prime} 09.57^{\prime \prime} \mathrm{E}$ & - \\
\hline 007.03 & 2009 & Tigzirt Port & $\mathrm{DZ}$ & $36^{\circ} 53^{\prime} 21.72^{\prime \prime} \mathrm{N}$ & $004^{\circ} 07^{\prime} 21.78^{\prime \prime} \mathrm{E}$ & - \\
\hline 007.04 & 1952 & Azazga & $\mathrm{DZ}$ & $36^{\circ} 45^{\prime} 21.10^{\prime \prime} \mathrm{N}$ & $004^{\circ} 23^{\prime} 19.55^{\prime \prime} \mathrm{E}$ & - \\
\hline 008.00 & 2014-03-22 & Oso-Steelhead & US & $48^{\circ} 17^{\prime} 06.57^{\prime \prime} \mathrm{N}$ & $121^{\circ} 51^{\prime} 03.33^{\prime \prime} \mathrm{W}$ & rain \\
\hline 009.01 & $1811-12-16$ & Stewart & US & $36^{\circ} 08^{\prime} 32.29^{\prime \prime} \mathrm{N}$ & $089^{\circ} 31^{\prime} 43.01^{\prime \prime} \mathrm{W}$ & New Madrid EQ (\#1) \\
\hline 009.02 & $1811-12-16$ & Campbell & US & $36^{\circ} 04^{\prime} 10.18^{\prime \prime} \mathrm{N}$ & $089^{\circ} 29^{\prime} 48.84^{\prime \prime} \mathrm{W}$ & New Madrid EQ (\#1) \\
\hline 010.00 & 1981-03 & Avignonet & FR & $44^{\circ} 56^{\prime} 45.29^{\prime \prime} \mathrm{N}$ & $005^{\circ} 40^{\prime} 47.37^{\prime \prime} \mathrm{E}$ & - \\
\hline 011.00 & paleo & Braemore & NZ & $39^{\circ} 41^{\prime} 29.60^{\prime \prime} \mathrm{S}$ & $174^{\circ} 39^{\prime} 18.97^{\prime \prime} \mathrm{E}$ & - \\
\hline 012.00 & 2001-01-13 & Las Colinas & SV & $13^{\circ} 39^{\prime} 46.27^{\prime \prime} \mathrm{N}$ & $089^{\circ} 17^{\prime} 11.17^{\prime \prime} \mathrm{W}$ & El Salvador EQ \\
\hline 013.00 & 1994-01-08 & La Salle en Beaumont & FR & $44^{\circ} 52^{\prime} 01.15^{\prime \prime} \mathrm{N}$ & $005^{\circ} 51^{\prime} 55.74^{\prime \prime} \mathrm{E}$ & - \\
\hline 014.00 & 1978 & Harmalière & FR & $44^{\circ} 56^{\prime} 07.42^{\prime \prime} \mathrm{N}$ & $005^{\circ} 40^{\prime} 13.33^{\prime \prime} \mathrm{E}$ & - \\
\hline 015.00 & $1980-11-23$ & Calitri & IT & $40^{\circ} 53^{\prime} 54.88^{\prime \prime} \mathrm{N}$ & $015^{\circ} 26^{\prime} 09.31^{\prime \prime} \mathrm{E}$ & Irpinia EQ \\
\hline 016.01 & 1999-09-20 & Tsaoling & TW & $23^{\circ} 35^{\prime} 06.14^{\prime \prime} \mathrm{N}$ & $120^{\circ} 40^{\prime} 40.83^{\prime \prime} \mathrm{E}$ & Chi Chi EQ \\
\hline 016.02 & 1999-09-20 & Jiufenershan & TW & $23^{\circ} 57^{\prime} 27.80^{\prime \prime} \mathrm{N}$ & $120^{\circ} 50^{\prime} 33.79^{\prime \prime} \mathrm{E}$ & Chi Chi EQ \\
\hline 016.03 & 1999-09-20 & Hungcaiping & TW & $23^{\circ} 57^{\prime} 23.82^{\prime \prime} \mathrm{N}$ & $120^{\circ} 48^{\prime} 56.63^{\prime \prime} \mathrm{E}$ & Chi Chi EQ \\
\hline 017.00 & 2009-08-09 & Shiaolin & TW & $23^{\circ} 09^{\prime} 54.85^{\prime \prime} \mathrm{N}$ & $120^{\circ} 40^{\prime} 00.84^{\prime \prime} \mathrm{E}$ & typhoon \\
\hline 018.01 & $?$ & Lesachriegel & $\mathrm{AT}$ & $46^{\circ} 59^{\prime} 17.01^{\prime \prime} \mathrm{N}$ & $012^{\circ} 40^{\prime} 58.39^{\prime \prime} \mathrm{E}$ & - \\
\hline 018.02 & $?$ & Gradenbach & AT & $46^{\circ} 59^{\prime} 54.02^{\prime \prime} \mathrm{N}$ & $012^{\circ} 51^{\prime} 00.36^{\prime \prime} \mathrm{E}$ & - \\
\hline 019.00 & 1903-04-29 & Frank & $\mathrm{CA}$ & $49^{\circ} 34^{\prime} 56.75^{\prime \prime} \mathrm{N}$ & $114^{\circ} 24^{\prime} 31.93^{\prime \prime} \mathrm{W}$ & - \\
\hline 020.01 & 1964-03-28 & Potter Hill & US & $61^{\circ} 05^{\prime} 23.00^{\prime \prime} \mathrm{N}$ & $149^{\circ} 50^{\prime} 44.50^{\prime \prime} \mathrm{W}$ & Alaska EQ \\
\hline 020.02 & 1964-03-28 & Bluff Road & US & $61^{\circ} 14^{\prime} 01.77^{\prime \prime} \mathrm{N}$ & $149^{\circ} 49^{\prime} 30.78^{\prime \prime} \mathrm{W}$ & Alaska EQ \\
\hline 020.03 & 1964-03-28 & Turnagain Heights & US & $61^{\circ} 11^{\prime} 56.42^{\prime \prime} \mathrm{N}$ & $149^{\circ} 57^{\prime} 43.95^{\prime \prime} \mathrm{W}$ & Alaska EQ \\
\hline 020.04 & 1964-03-28 & Point Campbell & US & $61^{\circ} 08^{\prime} 28.76^{\prime \prime} \mathrm{N}$ & $150^{\circ} 00^{\prime} 51.40^{\prime \prime} \mathrm{W}$ & Alaska EQ \\
\hline 020.05 & 1964-03-28 & Point Woronzof & US & $61^{\circ} 12^{\prime} 09.34^{\prime \prime} \mathrm{N}$ & $150^{\circ} 00^{\prime} 33.05^{\prime \prime} \mathrm{W}$ & Alaska EQ \\
\hline 020.06 & 1964-03-28 & L Street & US & $61^{\circ} 12^{\prime} 57.46^{\prime \prime} \mathrm{N}$ & $149^{\circ} 54^{\prime} 31.52^{\prime \prime} \mathrm{W}$ & Alaska EQ \\
\hline
\end{tabular}


Table A1. Cont.

\begin{tabular}{|c|c|c|c|c|c|c|}
\hline No. & Date & Landslide & C. & Latitude & Longitude & Trigger \\
\hline 020.07 & $1964-03-28$ & 4th Avenue & US & $61^{\circ} 13^{\prime} 11.81^{\prime \prime} \mathrm{N}$ & $149^{\circ} 53^{\prime} 05.80^{\prime \prime} \mathrm{W}$ & Alaska EQ \\
\hline 020.08 & $1964-03-28$ & Government Hill & US & $61^{\circ} 13^{\prime} 39.83^{\prime \prime} \mathrm{N}$ & $149^{\circ} 52^{\prime} 23.76^{\prime \prime} \mathrm{W}$ & Alaska EQ \\
\hline 020.09 & $1964-03-28$ & Native Hospital & US & $61^{\circ} 13^{\prime} 16.85^{\prime \prime} \mathrm{N}$ & $149^{\circ} 52^{\prime} 08.26^{\prime \prime} \mathrm{W}$ & Alaska EQ \\
\hline 021.00 & 1994-01-17 & Calabasas & US & $34^{\circ} 07^{\prime} 34.43^{\prime \prime} \mathrm{N}$ & $118^{\circ} 38^{\prime} 58.68^{\prime \prime} \mathrm{W}$ & Northridge EQ \\
\hline 022.00 & 1999-08-17 & Degirmendere & $\mathrm{TR}$ & $40^{\circ} 43^{\prime} 19.56^{\prime \prime} \mathrm{N}$ & $029^{\circ} 46^{\prime} 56.39^{\prime \prime} \mathrm{E}$ & Izmit EQ \\
\hline 023.01 & $?$ & Vaculov-Sedlo & $\mathrm{CZ}$ & $49^{\circ} 23^{\prime} 03.61^{\prime \prime} \mathrm{N}$ & $018^{\circ} 04^{\prime} 47.13^{\prime \prime} \mathrm{E}$ & - \\
\hline 023.02 & $?$ & Kobylska & $\mathrm{CZ}$ & $49^{\circ} 23^{\prime} 08.18^{\prime \prime} \mathrm{N}$ & $018^{\circ} 12^{\prime} 35.24^{\prime \prime} \mathrm{E}$ & - \\
\hline 023.03 & $?$ & Kopce & $\mathrm{CZ}$ & $49^{\circ} 13^{\prime} 20.54^{\prime \prime} \mathrm{N}$ & $018^{\circ} 02^{\prime} 25.59^{\prime \prime} \mathrm{E}$ & - \\
\hline 024.00 & 1980-05-18 & Mt. Saint Helens & US & $46^{\circ} 11^{\prime} 57.51^{\prime \prime} \mathrm{N}$ & $122^{\circ} 11^{\prime} 21.29^{\prime \prime} \mathrm{W}$ & volcanism \\
\hline 025.00 & paleo & Lluta & $\mathrm{CL}$ & $18^{\circ} 24^{\prime} 01.65^{\prime \prime} \mathrm{S}$ & $069^{\circ} 46^{\prime} 27.54^{\prime \prime} \mathrm{W}$ & - \\
\hline 026.00 & postglacial & Columbia Mountain & US & $48^{\circ} 20^{\prime} 18.79^{\prime \prime} \mathrm{N}$ & $114^{\circ} 07^{\prime} 12.57^{\prime \prime} \mathrm{W}$ & deglaciation \\
\hline 027.00 & 1990-06 & Eureka River & CA & $56^{\circ} 25^{\prime} 44.79^{\prime \prime} \mathrm{N}$ & $119^{\circ} 24^{\prime} 05.27^{\prime \prime} \mathrm{W}$ & undercutting \\
\hline 028.00 & 1939-04 & Montagneuse River & CA & $56^{\circ} 17^{\prime} 24.60^{\prime \prime} \mathrm{N}$ & $118^{\circ} 52^{\prime} 22.64^{\prime \prime} \mathrm{W}$ & - \\
\hline 029.00 & 1959-05-19 & Dunvegan & $\mathrm{CA}$ & $55^{\circ} 54^{\prime} 28.33^{\prime \prime} \mathrm{N}$ & $118^{\circ} 37^{\prime} 36.10^{\prime \prime} \mathrm{W}$ & - \\
\hline 030.01 & 2007-05-05 & Fox Creek East & CA & $55^{\circ} 51^{\prime} 23.82^{\prime \prime} \mathrm{N}$ & $118^{\circ} 03^{\prime} 25.25^{\prime \prime} \mathrm{W}$ & rain \\
\hline 030.02 & 2007-05-05 & Fox Creek West & $\mathrm{CA}$ & $55^{\circ} 51^{\prime} 32.65^{\prime \prime} \mathrm{N}$ & $118^{\circ} 04^{\prime} 08.23^{\prime \prime} \mathrm{W}$ & rain \\
\hline 031.01 & 1897 & CN50.9 & $\mathrm{CA}$ & $50^{\circ} 42^{\prime} 16.63^{\prime \prime} \mathrm{N}$ & $121^{\circ} 17^{\prime} 40.51^{\prime \prime} \mathrm{W}$ & undercutting \\
\hline 031.02 & 1886 & Goddart & $\mathrm{CA}$ & $50^{\circ} 41^{\prime} 14.78^{\prime \prime} \mathrm{N}$ & $121^{\circ} 17^{\prime} 43.30^{\prime \prime} \mathrm{W}$ & undercutting \\
\hline 032.00 & $1883-10-12$ & Beaver Creek & $\mathrm{CA}$ & $51^{\circ} 58^{\prime} 56.23^{\prime \prime} \mathrm{N}$ & $106^{\circ} 43^{\prime} 16.36^{\prime \prime} \mathrm{W}$ & - \\
\hline 033.01 & $?$ & Mt. Cefalone & IT & $42^{\circ} 14^{\prime} 31.49^{\prime \prime} \mathrm{N}$ & $013^{\circ} 25^{\prime} 13.51^{\prime \prime} \mathrm{E}$ & - \\
\hline 033.02 & $?$ & Cima della Fossa & IT & $41^{\circ} 54^{\prime} 06.97^{\prime \prime} \mathrm{N}$ & $014^{\circ} 01^{\prime} 32.86^{\prime \prime} \mathrm{E}$ & - \\
\hline 033.03 & $?$ & Villavallelonga & IT & $41^{\circ} 52^{\prime} 03.37^{\prime \prime} \mathrm{N}$ & $013^{\circ} 39^{\prime} 09.01^{\prime \prime} \mathrm{E}$ & - \\
\hline 033.04 & 1915-01-13 & Casali d'Aschi & IT & $41^{\circ} 58^{\prime} 01.77^{\prime \prime} \mathrm{N}$ & $013^{\circ} 40^{\prime} 56.76^{\prime \prime} \mathrm{E}$ & Avezzano EQ \\
\hline 033.05 & 1915-01-13 & Gioia dei Marsi & IT & $41^{\circ} 57^{\prime} 11.31^{\prime \prime} \mathrm{N}$ & $013^{\circ} 42^{\prime} 27.76^{\prime \prime} \mathrm{E}$ & Avezzano EQ \\
\hline 033.06 & 1703-01-14 & Mt. Alvagnano & IT & $42^{\circ} 40^{\prime} 19.15^{\prime \prime} \mathrm{N}$ & $013^{\circ} 08^{\prime} 40.50^{\prime \prime} \mathrm{E}$ & Norcia EQ \\
\hline 033.07 & $?$ & Fiamignano & IT & $42^{\circ} 16^{\prime} 28.61^{\prime \prime} \mathrm{N}$ & $013^{\circ} 07^{\prime} 19.02^{\prime \prime} \mathrm{E}$ & - \\
\hline 033.08 & $?$ & Pescasseroli & IT & $41^{\circ} 48^{\prime} 52.62^{\prime \prime} \mathrm{N}$ & $013^{\circ} 46^{\prime} 21.58^{\prime \prime} \mathrm{E}$ & - \\
\hline 034.00 & 1780 & Campo Vallemaggia & $\mathrm{CH}$ & $46^{\circ} 17^{\prime} 29.96^{\prime \prime} \mathrm{N}$ & $008^{\circ} 29^{\prime} 36.88^{\prime \prime} \mathrm{E}$ & - \\
\hline 035.01 & $?$ & Longobardi & IT & $39^{\circ} 12^{\prime} 41.17^{\prime \prime} \mathrm{N}$ & $016^{\circ} 04^{\prime} 19.73^{\prime \prime} \mathrm{E}$ & - \\
\hline 035.02 & $1982-12-13$ & Ancona & IT & $43^{\circ} 36^{\prime} 05.58^{\prime \prime} \mathrm{N}$ & $013^{\circ} 28^{\prime} 41.16^{\prime \prime} \mathrm{E}$ & - \\
\hline 036.00 & 1984-04 & La Clapière & FR & $44^{\circ} 15^{\prime} 08.16^{\prime \prime} \mathrm{N}$ & $006^{\circ} 56^{\prime} 29.22^{\prime \prime} \mathrm{E}$ & - \\
\hline 037.00 & 2006-03-21 & Laalam & $\mathrm{DZ}$ & $36^{\circ} 34^{\prime} 50.09^{\prime \prime} \mathrm{N}$ & $005^{\circ} 27^{\prime} 24.74^{\prime \prime} \mathrm{E}$ & Kherrata EQ \\
\hline 038.00 & 1806-09-02 & Goldau & $\mathrm{CH}$ & $47^{\circ} 04^{\prime} 36.94^{\prime \prime} \mathrm{N}$ & $008^{\circ} 33^{\prime} 40.84^{\prime \prime} \mathrm{E}$ & rain \\
\hline 039.01 & 1980 & Cerentino & $\mathrm{CH}$ & $46^{\circ} 18^{\prime} 23.34^{\prime \prime} \mathrm{N}$ & $008^{\circ} 32^{\prime} 20.52^{\prime \prime} \mathrm{E}$ & - \\
\hline 039.02 & 1834 & Peccia & $\mathrm{CH}$ & $46^{\circ} 24^{\prime} 56.52^{\prime \prime} \mathrm{N}$ & $008^{\circ} 40^{\prime} 29.50^{\prime \prime} \mathrm{E}$ & - \\
\hline 039.03 & 1846 & Val Canaria & $\mathrm{CH}$ & $46^{\circ} 33^{\prime} 25.52^{\prime \prime} \mathrm{N}$ & $008^{\circ} 38^{\prime} 49.57^{\prime \prime} \mathrm{E}$ & - \\
\hline 039.04 & $1896-10$ & Val Colla & $\mathrm{CH}$ & $46^{\circ} 05^{\prime} 15.13^{\prime \prime} \mathrm{N}$ & $009^{\circ} 01^{\prime} 08.71^{\prime \prime} \mathrm{E}$ & - \\
\hline 040.01 & 1755-11-01 & Güevéjar I & ES & $37^{\circ} 15^{\prime} 37.99^{\prime \prime} \mathrm{N}$ & $003^{\circ} 35^{\prime} 15.10^{\prime \prime} \mathrm{W}$ & Lisbon EQ \\
\hline 040.02 & $1884-12-25$ & Güevéjar II & ES & $37^{\circ} 15^{\prime} 37.99^{\prime \prime} \mathrm{N}$ & $003^{\circ} 35^{\prime} 15.10^{\prime \prime} \mathrm{W}$ & Arenas del Rey EQ \\
\hline 041.00 & 1683 & Montelparo & IT & $43^{\circ} 01^{\prime} 11.75^{\prime \prime} \mathrm{N}$ & $013^{\circ} 32^{\prime} 31.04^{\prime \prime} \mathrm{E}$ & - \\
\hline 042.00 & $1933-10$ & Sesa & IT & $45^{\circ} 54^{\prime} 01.40^{\prime \prime} \mathrm{N}$ & $010^{\circ} 20^{\prime} 14.35^{\prime \prime} \mathrm{E}$ & rain \\
\hline 043.01 & $?$ & Ráztoka & SK & $48^{\circ} 50^{\prime} 01.71^{\prime \prime} \mathrm{N}$ & $019^{\circ} 24^{\prime} 20.03^{\prime \prime} \mathrm{E}$ & - \\
\hline 043.02 & $?$ & Polská Tomanová & SK & $49^{\circ} 12^{\prime} 21.83^{\prime \prime} \mathrm{N}$ & $019^{\circ} 54^{\prime} 57.46^{\prime \prime} \mathrm{E}$ & - \\
\hline 044.00 & 2002-10-31 & Salcito & SK & $41^{\circ} 44^{\prime} 17.16^{\prime \prime} \mathrm{N}$ & $014^{\circ} 31^{\prime} 55.14^{\prime \prime} \mathrm{E}$ & Molise EQ \\
\hline 045.01 & paleo & Belbek & UA & $44^{\circ} 40^{\prime} 15.92^{\prime \prime} \mathrm{N}$ & $033^{\circ} 42^{\prime} 51.45^{\prime \prime} \mathrm{E}$ & EQ (?) \\
\hline 045.02 & paleo & Frontovoye & UA & $44^{\circ} 42^{\prime} 04.50^{\prime \prime} \mathrm{N}$ & $033^{\circ} 44^{\prime} 45.30^{\prime \prime} \mathrm{E}$ & EQ (?) \\
\hline 045.03 & paleo & Kacha 1 & UA & $44^{\circ} 44^{\prime} 47.93^{\prime \prime} \mathrm{N}$ & $033^{\circ} 43^{\prime} 47.38^{\prime \prime} \mathrm{E}$ & EQ (?) \\
\hline 045.04 & paleo & Kacha 2 & UA & $44^{\circ} 45^{\prime} 44.59^{\prime \prime} \mathrm{N}$ & $033^{\circ} 43^{\prime} 31.12^{\prime \prime} \mathrm{E}$ & EQ (?) \\
\hline 045.05 & paleo & Alma & UA & $44^{\circ} 51^{\prime} 16.53^{\prime \prime} \mathrm{N}$ & $033^{\circ} 52^{\prime} 43.01^{\prime \prime} \mathrm{E}$ & EQ (?) \\
\hline 045.06 & paleo & Vishennoye & UA & $45^{\circ} 07^{\prime} 57.59^{\prime \prime} \mathrm{N}$ & $034^{\circ} 36^{\prime} 59.23^{\prime \prime} \mathrm{E}$ & EQ (?) \\
\hline 046.01 & $1692-09-18$ & Battice 1 & $\mathrm{BE}$ & $50^{\circ} 39^{\prime} 13.63^{\prime \prime} \mathrm{N}$ & $005^{\circ} 50^{\prime} 24.10^{\prime \prime} \mathrm{E}$ & Verviers EQ \\
\hline 046.02 & $1692-09-18$ & Battice 2 & $\mathrm{BE}$ & $50^{\circ} 39^{\prime} 00.46^{\prime \prime} \mathrm{N}$ & $005^{\circ} 50^{\prime} 32.57^{\prime \prime} \mathrm{E}$ & Verviers EQ \\
\hline 046.03 & $1692-09-18$ & Battice 3 & $\mathrm{BE}$ & $50^{\circ} 38^{\prime} 52.31^{\prime \prime} \mathrm{N}$ & $005^{\circ} 50^{\prime} 51.36^{\prime \prime} \mathrm{E}$ & Verviers EQ \\
\hline 046.04 & $1692-09-18$ & Battice 4 & $\mathrm{BE}$ & $50^{\circ} 38^{\prime} 58.66^{\prime \prime} \mathrm{N}$ & $005^{\circ} 51^{\prime} 29.41^{\prime \prime} \mathrm{E}$ & Verviers EQ \\
\hline 046.05 & 1692-09-18 & Battice 5 & $\mathrm{BE}$ & $50^{\circ} 39^{\prime} 00.28^{\prime \prime} \mathrm{N}$ & $005^{\circ} 51^{\prime} 59.18^{\prime \prime} \mathrm{E}$ & Verviers EQ \\
\hline 046.06 & $1692-09-18$ & Battice 6 & $\mathrm{BE}$ & $50^{\circ} 39^{\prime} 06.65^{\prime \prime} \mathrm{N}$ & $005^{\circ} 52^{\prime} 35.11^{\prime \prime} \mathrm{E}$ & Verviers EQ \\
\hline 046.07 & $1692-09-18$ & Battice 7 & $\mathrm{BE}$ & $50^{\circ} 39^{\prime} 41.62^{\prime \prime} \mathrm{N}$ & $005^{\circ} 52^{\prime} 38.99^{\prime \prime} \mathrm{E}$ & Verviers EQ \\
\hline 046.08 & $1692-09-18$ & Battice 8 & $\mathrm{BE}$ & $50^{\circ} 38^{\prime} 27.28^{\prime \prime} \mathrm{N}$ & $005^{\circ} 51^{\prime} 09.95^{\prime \prime} \mathrm{E}$ & Verviers EQ \\
\hline 046.09 & $1692-09-18$ & Battice 9 & $\mathrm{BE}$ & $50^{\circ} 38^{\prime} 37.36^{\prime \prime} \mathrm{N}$ & $005^{\circ} 51^{\prime} 52.67^{\prime \prime} \mathrm{E}$ & Verviers EQ \\
\hline 046.10 & $1692-09-18$ & Battice 10 & $\mathrm{BE}$ & $50^{\circ} 38^{\prime} 35.84^{\prime \prime} \mathrm{N}$ & $005^{\circ} 50^{\prime} 45.61^{\prime \prime} \mathrm{E}$ & Verviers EQ \\
\hline 046.11 & $1692-09-18$ & Battice 11 & $\mathrm{BE}$ & $50^{\circ} 37^{\prime} 53.96^{\prime \prime} \mathrm{N}$ & $005^{\circ} 49^{\prime} 40.06^{\prime \prime} \mathrm{E}$ & Verviers EQ \\
\hline 046.12 & $1692-09-18$ & Battice 12 & $\mathrm{BE}$ & $50^{\circ} 37^{\prime} 45.13^{\prime \prime} \mathrm{N}$ & $005^{\circ} 49^{\prime} 40.99^{\prime \prime} \mathrm{E}$ & Verviers EQ \\
\hline 046.13 & $1692-09-18$ & Battice 13 (Manaihan) & $\mathrm{BE}$ & $50^{\circ} 37^{\prime} 34.66^{\prime \prime} \mathrm{N}$ & $005^{\circ} 49^{\prime} 40.57^{\prime \prime} \mathrm{E}$ & Verviers EQ \\
\hline 047.01 & 2007-04-21 & Acantilada Bay & $\mathrm{CL}$ & $45^{\circ} 23^{\prime} 49.80^{\prime \prime} \mathrm{S}$ & $072^{\circ} 53^{\prime} 09.00^{\prime \prime} \mathrm{W}$ & Aysén EQ \\
\hline 047.02 & 2007-04-21 & Punta Cola & CL & $45^{\circ} 22^{\prime} 46.80^{\prime \prime} \mathrm{S}$ & $072^{\circ} 59^{\prime} 54.00^{\prime \prime} \mathrm{W}$ & Aysén EQ \\
\hline 047.03 & 2007-04-21 & Mentirosa Island & CL & $45^{\circ} 24^{\prime} 03.00^{\prime \prime} \mathrm{S}$ & $072^{\circ} 58^{\prime} 05.40^{\prime \prime} \mathrm{W}$ & Aysén EQ \\
\hline 047.04 & 2007-04-21 & Frío Creek & $\mathrm{CL}$ & $45^{\circ} 23^{\prime} 55.20^{\prime \prime} \mathrm{S}$ & $072^{\circ} 56^{\prime} 40.20^{\prime \prime} \mathrm{W}$ & Aysén EQ \\
\hline
\end{tabular}


Table A1. Cont.

\begin{tabular}{|c|c|c|c|c|c|c|}
\hline No. & Date & Landslide & C. & Latitude & Longitude & Trigger \\
\hline 047.05 & 2007-04-21 & Marta River 1 & CL & $45^{\circ} 20^{\prime} 19.80^{\prime \prime} \mathrm{S}$ & $073^{\circ} 00^{\prime} 15.60^{\prime \prime} \mathrm{W}$ & Aysén EQ \\
\hline 047.06 & 2007-04-21 & Fernández Creek & CL & $45^{\circ} 23^{\prime} 25.20^{\prime \prime} \mathrm{S}$ & $072^{\circ} 54^{\prime} 17.40^{\prime \prime} \mathrm{W}$ & Aysén EQ \\
\hline 047.07 & 2007-04-21 & Marta River 2 & $\mathrm{CL}$ & $45^{\circ} 20^{\prime} 56.40^{\prime \prime} \mathrm{S}$ & $072^{\circ} 58^{\prime} 52.20^{\prime \prime} \mathrm{W}$ & Aysén EQ \\
\hline 047.08 & 2007-04-21 & Pescado River & CL & $45^{\circ} 25^{\prime} 26.40^{\prime \prime} \mathrm{S}$ & $073^{\circ} 06^{\prime} 05.40^{\prime \prime} \mathrm{W}$ & Aysén EQ \\
\hline 048.00 & 1987-03-05 & Salado & $\mathrm{EC}$ & $00^{\circ} 11^{\prime} 27.68^{\prime \prime} \mathrm{S}$ & $077^{\circ} 41^{\prime} 39.36^{\prime \prime} \mathrm{W}$ & Ecuador EQ \\
\hline 049.00 & 1679-06-04 & Vokhchaberd & $\mathrm{AM}$ & $40^{\circ} 09^{\prime} 59.75^{\prime \prime} \mathrm{N}$ & $044^{\circ} 38^{\prime} 17.21^{\prime \prime} \mathrm{E}$ & Armenia EQ \\
\hline 050.00 & 1881-09-10 & Castel Frentano & IT & $42^{\circ} 11^{\prime} 55.53^{\prime \prime} \mathrm{N}$ & $014^{\circ} 21^{\prime} 35.41^{\prime \prime} \mathrm{E}$ & Lanciano EQ \\
\hline 051.00 & 1997-10-11 & Mt. Nuria & IT & $42^{\circ} 21^{\prime} 44.73^{\prime \prime} \mathrm{N}$ & $013^{\circ} 00^{\prime} 21.11^{\prime \prime} \mathrm{E}$ & - \\
\hline 052.01 & 1990-06-20 & Galdian & IR & $36^{\circ} 48^{\prime} 01.95^{\prime \prime} \mathrm{N}$ & $049^{\circ} 25^{\prime} 37.05^{\prime \prime} \mathrm{E}$ & Manjil-Rudbar EQ \\
\hline 052.02 & 1990-06-20 & Fatalak & IR & $36^{\circ} 50^{\prime} 20.41^{\prime \prime} \mathrm{N}$ & $049^{\circ} 29^{\prime} 13.48^{\prime \prime} \mathrm{E}$ & Manjil-Rudbar EQ \\
\hline 053.00 & 1963-10-09 & Vajont & IT & $46^{\circ} 15^{\prime} 27.65^{\prime \prime} \mathrm{N}$ & $012^{\circ} 20^{\prime} 25.93^{\prime \prime} \mathrm{E}$ & rain, GW, bedding \\
\hline 054.00 & 2003-09-10 & Tsaitichhu & BT & $27^{\circ} 25^{\prime} 52.19^{\prime \prime} \mathrm{N}$ & $091^{\circ} 06^{\prime} 40.49^{\prime \prime} \mathrm{E}$ & - \\
\hline 055.00 & 2007-03-01 & S. Giovanni & IT & $38^{\circ} 16^{\prime} 11.31^{\prime \prime} \mathrm{N}$ & $015^{\circ} 47^{\prime} 54.28^{\prime \prime} \mathrm{E}$ & tunneling \\
\hline 056.00 & 1950 & Rasdeglia & IT & $46^{\circ} 27^{\prime} 29.72^{\prime \prime} \mathrm{N}$ & $009^{\circ} 19^{\prime} 07.28^{\prime \prime} \mathrm{E}$ & - \\
\hline 057.00 & 1992-08-19 & Suusamyr & KG & $42^{\circ} 12^{\prime} 29.82^{\prime \prime} \mathrm{N}$ & $073^{\circ} 36^{\prime} 33.08^{\prime \prime} \mathrm{E}$ & Suusamyr EQ \\
\hline 058.01 & paleo & Kokomeren & KG & $41^{\circ} 55^{\prime} 35.84^{\prime \prime} \mathrm{N}$ & $074^{\circ} 13^{\prime} 35.99^{\prime \prime} \mathrm{E}$ & EQ (?) \\
\hline 058.02 & 1885 & Aksu & KG & $42^{\circ} 32^{\prime} 33.01^{\prime \prime} \mathrm{N}$ & $073^{\circ} 59^{\prime} 21.27^{\prime \prime} \mathrm{E}$ & Belovodsk EQ (?) \\
\hline 058.03 & paleo & Beshkiol & KG & $41^{\circ} 25^{\prime} 00.00^{\prime \prime} \mathrm{N}$ & $074^{\circ} 30^{\prime} 00.00^{\prime \prime} \mathrm{E}$ & EQ (?) \\
\hline 058.04 & paleo & Karakudjur & KG & $41^{\circ} 57^{\prime} 43.72^{\prime \prime} \mathrm{N}$ & $075^{\circ} 53^{\prime} 09.05^{\prime \prime} \mathrm{E}$ & EQ (?) \\
\hline 058.05 & 1946 & Sarychelek & KG & $41^{\circ} 52^{\prime} 00.00^{\prime \prime} \mathrm{N}$ & $072^{\circ} 00^{\prime} 00.00^{\prime \prime} \mathrm{E}$ & Chatkal EQ (?) \\
\hline 058.06 & paleo & Kugart & KG & $41^{\circ} 10^{\prime} 00.00^{\prime \prime} \mathrm{N}$ & $073^{\circ} 20^{\prime} 60.00^{\prime \prime} \mathrm{E}$ & EQ (?) \\
\hline 059.00 & $?$ & Rosone & IT & $45^{\circ} 26^{\prime} 17.72^{\prime \prime} \mathrm{N}$ & $007^{\circ} 23^{\prime} 58.78^{\prime \prime} \mathrm{E}$ & rain \\
\hline 060.00 & 2000-04-09 & Yigong & $\mathrm{CN}$ & $30^{\circ} 13^{\prime} 46.30^{\prime \prime} \mathrm{N}$ & $094^{\circ} 59^{\prime} 28.88^{\prime \prime} \mathrm{E}$ & - \\
\hline 061.00 & 1911-02-18 & Usoi & $\mathrm{TJ}$ & $38^{\circ} 18^{\prime} 21.64^{\prime \prime} \mathrm{N}$ & $072^{\circ} 36^{\prime} 46.40^{\prime \prime} \mathrm{E}$ & Sarez EQ \\
\hline 062.01 & $1989-01-22$ & Okuli & TJ & $38^{\circ} 29^{\prime} 10.43^{\prime \prime} \mathrm{N}$ & $068^{\circ} 37^{\prime} 41.70^{\prime \prime} \mathrm{E}$ & Gissar EQ \\
\hline 062.02 & 1989-01-22 & May 1 & TJ & $38^{\circ} 29^{\prime} 15.91^{\prime \prime} \mathrm{N}$ & $068^{\circ} 37^{\prime} 21.13^{\prime \prime} \mathrm{E}$ & Gissar EQ \\
\hline 062.03 & $1989-01-22$ & Firma & TJ & $38^{\circ} 29^{\prime} 23.60^{\prime \prime} \mathrm{N}$ & $068^{\circ} 38^{\prime} 19.45^{\prime \prime} \mathrm{E}$ & Gissar EQ \\
\hline 062.04 & 1989-01-22 & Sharara & TJ & $38^{\circ} 29^{\prime} 17.39^{\prime \prime} \mathrm{N}$ & $068^{\circ} 38^{\prime} 51.46^{\prime \prime} \mathrm{E}$ & Gissar EQ \\
\hline 063.00 & 1984 & Klasgarten & $\mathrm{AT}$ & $46^{\circ} 57^{\prime} 08.59^{\prime \prime} \mathrm{N}$ & $010^{\circ} 45^{\prime} 02.24^{\prime \prime} \mathrm{E}$ & - \\
\hline 064.00 & 1975 & Niedergallmigg & $\mathrm{AT}$ & $47^{\circ} 06^{\prime} 04.31^{\prime \prime} \mathrm{N}$ & $010^{\circ} 36^{\prime} 30.03^{\prime \prime} \mathrm{E}$ & - \\
\hline 065.01 & 1992 & Huayuanyangjichang & $\mathrm{CN}$ & $30^{\circ} 44^{\prime} 57.32^{\prime \prime} \mathrm{N}$ & $108^{\circ} 25^{\prime} 43.70^{\prime \prime} \mathrm{E}$ & GW \\
\hline 065.02 & 1996 & Jinjinzi & $\mathrm{CN}$ & $30^{\circ} 33^{\prime} 39.48^{\prime \prime} \mathrm{N}$ & $108^{\circ} 18^{\prime} 17.38^{\prime \prime} \mathrm{E}$ & GW \\
\hline 065.03 & 1999 & Yangjiaba & $\mathrm{CN}$ & $30^{\circ} 26^{\prime} 05.48^{\prime \prime} \mathrm{N}$ & $108^{\circ} 14^{\prime} 10.50^{\prime \prime} \mathrm{E}$ & GW \\
\hline 066.00 & postglacial & Atemkopf & AT & $46^{\circ} 56^{\prime} 34.29^{\prime \prime} \mathrm{N}$ & $010^{\circ} 43^{\prime} 19.17^{\prime \prime} \mathrm{E}$ & - \\
\hline 067.00 & $2002-10$ & La Mania & IT & $46^{\circ} 27^{\prime} 24.06^{\prime \prime} \mathrm{N}$ & $012^{\circ} 43^{\prime} 41.15^{\prime \prime} \mathrm{E}$ & - \\
\hline 068.00 & 1960 & Beauregard & IT & $45^{\circ} 37^{\prime} 09.03^{\prime \prime} \mathrm{N}$ & $007^{\circ} 02^{\prime} 36.21^{\prime \prime} \mathrm{E}$ & - \\
\hline 069.00 & 1965-01-09 & Hope & $\mathrm{CA}$ & $49^{\circ} 18^{\prime} 21.72^{\prime \prime} \mathrm{N}$ & $121^{\circ} 14^{\prime} 22.42^{\prime \prime} \mathrm{W}$ & EQ (?) \\
\hline 070.00 & $?$ & Anlesi & $\mathrm{CN}$ & $30^{\circ} 49^{\prime} 45.44^{\prime \prime} \mathrm{N}$ & $108^{\circ} 20^{\prime} 38.63^{\prime \prime} \mathrm{E}$ & rain \\
\hline 071.01 & $1914-05-30$ & Cà di Malta & IT & $44^{\circ} 17^{\prime} 26.61^{\prime \prime} \mathrm{N}$ & $011^{\circ} 07^{\prime} 14.63^{\prime \prime} \mathrm{E}$ & - \\
\hline 071.02 & 1934-03-06 & Rocca Pitigliana & IT & $44^{\circ} 13^{\prime} 56.49^{\prime \prime} \mathrm{N}$ & $011^{\circ} 00^{\prime} 11.74^{\prime \prime} \mathrm{E}$ & - \\
\hline 072.00 & 1957-07-02 & Kahrod & IR & $36^{\circ} 03^{\prime} 59.80^{\prime \prime} \mathrm{N}$ & $052^{\circ} 14^{\prime} 36.17^{\prime \prime} \mathrm{E}$ & Mazandaran EQ \\
\hline 073.00 & 2008-09 & Cerca del Cielo & US & $18^{\circ} 02^{\prime} 22.22^{\prime \prime} \mathrm{N}$ & $066^{\circ} 40^{\prime} 28.98^{\prime \prime} \mathrm{W}$ & rain \\
\hline 074.00 & $?$ & Kutlugün & TR & $40^{\circ} 56^{\prime} 31.61^{\prime \prime} \mathrm{N}$ & $039^{\circ} 43^{\prime} 58.04^{\prime \prime} \mathrm{E}$ & - \\
\hline 075.00 & 1987-07-28 & Val Pola & IT & $46^{\circ} 22^{\prime} 42.87^{\prime \prime} \mathrm{N}$ & $010^{\circ} 20^{\prime} 11.95^{\prime \prime} \mathrm{E}$ & rain \\
\hline 076.01 & $?$ & Varco d'Izzo & IT & $40^{\circ} 38^{\prime} 45.97^{\prime \prime} \mathrm{N}$ & $015^{\circ} 51^{\prime} 40.67^{\prime \prime} \mathrm{E}$ & - \\
\hline 076.02 & $?$ & Costa della Gaveta & IT & $40^{\circ} 38^{\prime} 40.44^{\prime \prime} \mathrm{N}$ & $015^{\circ} 51^{\prime} 07.42^{\prime \prime} \mathrm{E}$ & - \\
\hline 077.00 & 1979-08-08 & Abbotsford & $\mathrm{NZ}$ & $45^{\circ} 53^{\prime} 37.02^{\prime \prime} \mathrm{S}$ & $170^{\circ} 26^{\prime} 16.35^{\prime \prime} \mathrm{E}$ & mining \\
\hline 078.00 & 17th cent. & Tortum & $\mathrm{TT}$ & $40^{\circ} 39^{\prime} 56.10^{\prime \prime} \mathrm{N}$ & $041^{\circ} 38^{\prime} 31.18^{\prime \prime} \mathrm{E}$ & EQ (?) \\
\hline 079.00 & 18th cent. & Slumgullion & US & $37^{\circ} 59^{\prime} 36.97^{\prime \prime} \mathrm{N}$ & $107^{\circ} 15^{\prime} 11.29^{\prime \prime} \mathrm{W}$ & rain \\
\hline 080.00 & 1999-05-13 & Rufi & $\mathrm{CH}$ & $47^{\circ} 11^{\prime} 15.97^{\prime \prime} \mathrm{N}$ & $009^{\circ} 04^{\prime} 46.13^{\prime \prime} \mathrm{E}$ & rain \\
\hline 081.00 & 2007 & Zhujiadian & $\mathrm{CN}$ & $31^{\circ} 02^{\prime} 48.86^{\prime \prime} \mathrm{N}$ & $110^{\circ} 23^{\prime} 57.86^{\prime \prime} \mathrm{E}$ & GW \\
\hline 082.00 & 1982 & Minor Creek & US & $40^{\circ} 57^{\prime} 57.27^{\prime \prime} \mathrm{N}$ & $123^{\circ} 49^{\prime} 59.74^{\prime \prime} \mathrm{W}$ & rain \\
\hline 083.00 & 2005-03-17 & Kuzulu & $\mathrm{TR}$ & $40^{\circ} 20^{\prime} 50.13^{\prime \prime} \mathrm{N}$ & $037^{\circ} 39^{\prime} 16.20^{\prime \prime} \mathrm{E}$ & snowmelt \\
\hline 084.00 & 1995 & Huangtupo & $\mathrm{CN}$ & $31^{\circ} 02^{\prime} 34.17^{\prime \prime} \mathrm{N}$ & $110^{\circ} 23^{\prime} 07.89^{\prime \prime} \mathrm{E}$ & GW \\
\hline 085.00 & 1998 & Fosso Spineto & IT & $40^{\circ} 37^{\prime} 38.66^{\prime \prime} \mathrm{N}$ & $016^{\circ} 17^{\prime} 28.67^{\prime \prime} \mathrm{E}$ & undercutting \\
\hline 086.00 & $500000 \mathrm{BP}$ & Marcus & US & $33^{\circ} 40^{\prime} 47.72^{\prime \prime} \mathrm{N}$ & $111^{\circ} 47^{\prime} 50.06^{\prime \prime} \mathrm{W}$ & - \\
\hline 087.00 & 2003-11-09 & Afternoon Creek & US & $48^{\circ} 41^{\prime} 33.94^{\prime \prime} \mathrm{N}$ & $121^{\circ} 14^{\prime} 23.26^{\prime \prime} \mathrm{W}$ & rain \\
\hline 088.00 & 2009-04-26 & Valgrisenche & IT & $45^{\circ} 41^{\prime} 05.20^{\prime \prime} \mathrm{N}$ & $007^{\circ} 07^{\prime} 12.24^{\prime \prime} \mathrm{E}$ & rain \\
\hline 089.00 & $?$ & Aka-Kuzure & $\mathrm{JP}$ & $35^{\circ} 21^{\prime} 28.03^{\prime \prime} \mathrm{N}$ & $138^{\circ} 12^{\prime} 26.26^{\prime \prime} \mathrm{E}$ & - \\
\hline 090.00 & $?$ & Ivancich & IT & $43^{\circ} 04^{\prime} 00.00^{\prime \prime} \mathrm{N}$ & $012^{\circ} 37^{\prime} 30.00^{\prime \prime} \mathrm{E}$ & - \\
\hline 091.00 & 1999-11-12 & Bakacak & TR & $40^{\circ} 45^{\prime} 19.23^{\prime \prime} \mathrm{N}$ & $031^{\circ} 22^{\prime} 18.69^{\prime \prime} \mathrm{E}$ & Düzce EQ \\
\hline 092.00 & postglacial & Triesenberg & LI & $47^{\circ} 07^{\prime} 06.22^{\prime \prime} \mathrm{N}$ & $009^{\circ} 32^{\prime} 54.51^{\prime \prime} \mathrm{E}$ & deglaciation \\
\hline 093.00 & $1783-02-06$ & Scilla & IT & $38^{\circ} 14^{\prime} 53.00^{\prime \prime} \mathrm{N}$ & $015^{\circ} 42^{\prime} 05.84^{\prime \prime} \mathrm{E}$ & Calabria EQ (\#2) \\
\hline 094.00 & 1972 & San Donato & IT & $40^{\circ} 23^{\prime} 31.15^{\prime \prime} \mathrm{N}$ & $016^{\circ} 33^{\prime} 54.20^{\prime \prime} \mathrm{E}$ & - \\
\hline 095.00 & $?$ & La Salsa & IT & $40^{\circ} 31^{\prime} 09.71^{\prime \prime} \mathrm{N}$ & $016^{\circ} 32^{\prime} 50.78^{\prime \prime} \mathrm{E}$ & - \\
\hline 096.00 & 1996 & Grohovo & HR & $45^{\circ} 21^{\prime} 58.08^{\prime \prime} \mathrm{N}$ & $014^{\circ} 26^{\prime} 53.11^{\prime \prime} \mathrm{E}$ & - \\
\hline 097.00 & $35000 \mathrm{BP}$ & Uspenskoye & RU & $44^{\circ} 53^{\prime} 14.01^{\prime \prime} \mathrm{N}$ & $041^{\circ} 25^{\prime} 29.77^{\prime \prime} \mathrm{E}$ & EQ (?) \\
\hline 098.00 & 1995-01-16 & Nikawa & $\mathrm{JP}$ & $34^{\circ} 46^{\prime} 23.83^{\prime \prime} \mathrm{N}$ & $135^{\circ} 20^{\prime} 29.40^{\prime \prime} \mathrm{E}$ & Kobe EQ \\
\hline 099.00 & paleo & Dúdar & ES & $37^{\circ} 11^{\prime} 39.28^{\prime \prime} \mathrm{N}$ & $003^{\circ} 29^{\prime} 19.66^{\prime \prime} \mathrm{W}$ & EQ (?) \\
\hline
\end{tabular}


Table A1. Cont.

\begin{tabular}{|c|c|c|c|c|c|c|}
\hline No. & Date & Landslide & C. & Latitude & Longitude & Trigger \\
\hline 100.01 & $?$ & Machu Picchu A & $\mathrm{PE}$ & $13^{\circ} 09^{\prime} 58.60^{\prime \prime} \mathrm{S}$ & $072^{\circ} 32^{\prime} 26.91^{\prime \prime} \mathrm{W}$ & GW, faults \\
\hline 100.02 & $?$ & Machu Picchu B & PE & $13^{\circ} 09^{\prime} 48.07^{\prime \prime} \mathrm{S}$ & $072^{\circ} 32^{\prime} 41.83^{\prime \prime} \mathrm{W}$ & GW, faults \\
\hline 101.01 & 2002 & Keillor Road & CA & $53^{\circ} 30^{\prime} 41.08^{\prime \prime} \mathrm{N}$ & $113^{\circ} 32^{\prime} 28.92^{\prime \prime} \mathrm{W}$ & GW \\
\hline 101.02 & $1999-10-23$ & Whitemud Road & CA & $53^{\circ} 28^{\prime} 56.19^{\prime \prime} \mathrm{N}$ & $113^{\circ} 35^{\prime} 17.61^{\prime \prime} \mathrm{W}$ & GW \\
\hline 102.00 & $1627-07-30$ & Vasto & IT & $42^{\circ} 06^{\prime} 16.33^{\prime \prime} \mathrm{N}$ & $014^{\circ} 42^{\prime} 50.53^{\prime \prime} \mathrm{E}$ & Gargano EQ (?) \\
\hline 103.00 & 1963 & Kostanjek & HR & $45^{\circ} 49^{\prime} 15.46^{\prime \prime} \mathrm{N}$ & $015^{\circ} 51^{\prime} 22.44^{\prime \prime} \mathrm{E}$ & GW, mining \\
\hline 104.00 & 1997-07 & Mt. Munday & HR & $51^{\circ} 20^{\prime} 46.26^{\prime \prime} \mathrm{N}$ & $125^{\circ} 14^{\prime} 29.02^{\prime \prime} \mathrm{W}$ & - \\
\hline 105.00 & 2010-08-06 & Mt. Meager & HR & $50^{\circ} 37^{\prime} 27.17^{\prime \prime} \mathrm{N}$ & $123^{\circ} 30^{\prime} 05.53^{\prime \prime} \mathrm{W}$ & volcanism \\
\hline 106.00 & $10000 \mathrm{BP}$ & Downie & HR & $51^{\circ} 30^{\prime} 17.38^{\prime \prime} \mathrm{N}$ & $118^{\circ} 32^{\prime} 06.37^{\prime \prime} \mathrm{W}$ & deglaciation \\
\hline 107.00 & 2005-01-10 & La Conchita & US & $34^{\circ} 21^{\prime} 54.51^{\prime \prime} \mathrm{N}$ & $119^{\circ} 26^{\prime} 40.69^{\prime \prime} \mathrm{W}$ & rain \\
\hline 108.00 & postglacial & Séchilienne & FR & $45^{\circ} 03^{\prime} 49.44^{\prime \prime} \mathrm{N}$ & $005^{\circ} 48^{\prime} 16.13^{\prime \prime} \mathrm{E}$ & - \\
\hline 109.00 & 2004 & Ogoto & $\mathrm{JP}$ & $?$ & $?$ & GW \\
\hline 110.00 & 2003 & Kuchi-Otani & $\mathrm{JP}$ & $?$ & $?$ & typhoon \\
\hline 111.00 & $1854-12-23$ & Zentoku & $\mathrm{JP}$ & $33^{\circ} 53^{\prime} 07.14^{\prime \prime} \mathrm{N}$ & $133^{\circ} 50^{\prime} 19.94^{\prime \prime} \mathrm{E}$ & Tokai EQ (?) \\
\hline 112.00 & $2003-05-26$ & Tsukidate & $\mathrm{JP}$ & $38^{\circ} 43^{\prime} 41.19^{\prime \prime} \mathrm{N}$ & $141^{\circ} 00^{\prime} 35.41^{\prime \prime} \mathrm{E}$ & Sanriku-Minami EQ \\
\hline 113.01 & 1997-01 & Slesse Park & CA & $49^{\circ} 05^{\prime} 05.87^{\prime \prime} \mathrm{N}$ & $121^{\circ} 48^{\prime} 27.42^{\prime \prime} \mathrm{W}$ & rain, logging \\
\hline 113.02 & $1973-05-26$ & Attachie & CA & $56^{\circ} 12^{\prime} 13.84^{\prime \prime} \mathrm{N}$ & $121^{\circ} 27^{\prime} 19.17^{\prime \prime} \mathrm{W}$ & rain \\
\hline 114.00 & 1963-09-03 & Lesueur & CA & $53^{\circ} 36^{\prime} 05.81^{\prime \prime} \mathrm{N}$ & $113^{\circ} 18^{\prime} 41.57^{\prime \prime} \mathrm{W}$ & mining \\
\hline 115.00 & 1933-07 & Brazeau & $\mathrm{CA}$ & $52^{\circ} 23^{\prime} 21.12^{\prime \prime} \mathrm{N}$ & $117^{\circ} 04^{\prime} 19.41^{\prime \prime} \mathrm{W}$ & - \\
\hline 116.00 & 1990-06-17 & Saddle River & $\mathrm{CA}$ & $55^{\circ} 47^{\prime} 12.20^{\prime \prime} \mathrm{N}$ & $118^{\circ} 26^{\prime} 20.37^{\prime \prime} \mathrm{W}$ & rain \\
\hline 117.00 & 2010-01 & Cenes de la Vega & ES & $37^{\circ} 10^{\prime} 24.38^{\prime \prime} \mathrm{N}$ & $003^{\circ} 32^{\prime} 01.50^{\prime \prime} \mathrm{W}$ & rain, pipe leak \\
\hline 118.00 & $1993-12-29$ & Acquara-Vadoncello & IT & $40^{\circ} 44^{\prime} 03.30^{\prime \prime} \mathrm{N}$ & $015^{\circ} 12^{\prime} 42.45^{\prime \prime} \mathrm{E}$ & - \\
\hline 119.00 & 1901-10-01 & Boscobel & $\mathrm{BB}$ & $13^{\circ} 16^{\prime} 27.13^{\prime \prime} \mathrm{N}$ & $059^{\circ} 34^{\prime} 19.83^{\prime \prime} \mathrm{W}$ & - \\
\hline 120.00 & paleo & Mt. Nuovo & IT & $40^{\circ} 44^{\prime} 08.83^{\prime \prime} \mathrm{N}$ & $013^{\circ} 53^{\prime} 17.08^{\prime \prime} \mathrm{E}$ & volcanism \\
\hline 121.00 & $140000 \mathrm{BP}$ & Baga Bogd & $\mathrm{MN}$ & $44^{\circ} 57^{\prime} 37.88^{\prime \prime} \mathrm{N}$ & $101^{\circ} 32^{\prime} 23.34^{\prime \prime} \mathrm{E}$ & deglaciation \\
\hline 122.00 & $1974-04-25$ & Mayunmarca & PE & $12^{\circ} 39^{\prime} 12.37^{\prime \prime} \mathrm{S}$ & $074^{\circ} 41^{\prime} 43.58^{\prime \prime} \mathrm{W}$ & - \\
\hline 123.00 & 1612 & Corniglio & IT & $44^{\circ} 28^{\prime} 00.76^{\prime \prime} \mathrm{N}$ & $010^{\circ} 04^{\prime} 40.82^{\prime \prime} \mathrm{E}$ & - \\
\hline 124.00 & $?$ & Vallcebre & ES & $42^{\circ} 12^{\prime} 21.23^{\prime \prime} \mathrm{N}$ & $001^{\circ} 49^{\prime} 59.40^{\prime \prime} \mathrm{E}$ & - \\
\hline 125.00 & $10000 \mathrm{BP}$ & Corvara & IT & $46^{\circ} 32^{\prime} 19.74^{\prime \prime} \mathrm{N}$ & $011^{\circ} 54^{\prime} 13.37^{\prime \prime} \mathrm{E}$ & - \\
\hline 126.00 & 1786-06-01 & Dadu River & $\mathrm{CN}$ & $29^{\circ} 37^{\prime} 52.69^{\prime \prime} \mathrm{N}$ & $102^{\circ} 09^{\prime} 28.84^{\prime \prime} \mathrm{E}$ & Kangding EQ \\
\hline 127.00 & 10000 BP & Fogo & $\mathrm{CV}$ & $14^{\circ} 57^{\prime} 06.61^{\prime \prime} \mathrm{N}$ & $024^{\circ} 21^{\prime} 32.88^{\prime \prime} \mathrm{W}$ & volcanism \\
\hline 128.00 & 1906 & Petacciato & IT & $42^{\circ} 01^{\prime} 07.49^{\prime \prime} \mathrm{N}$ & $014^{\circ} 52^{\prime} 39.16^{\prime \prime} \mathrm{E}$ & - \\
\hline 129.01 & $20000 \mathrm{BP}$ & El Petruso & ES & $42^{\circ} 48^{\prime} 03.45^{\prime \prime} \mathrm{N}$ & $000^{\circ} 24^{\prime} 33.85^{\prime \prime} \mathrm{W}$ & rain \\
\hline 129.02 & $20000 \mathrm{BP}$ & Sextas & ES & $42^{\circ} 46^{\prime} 12.79^{\prime \prime} \mathrm{N}$ & $000^{\circ} 22^{\prime} 31.28^{\prime \prime} \mathrm{W}$ & rain \\
\hline 129.03 & 20000 BP & La Selva & ES & $42^{\circ} 45^{\prime} 43.54^{\prime \prime} \mathrm{N}$ & $000^{\circ} 21^{\prime} 10.30^{\prime \prime} \mathrm{W}$ & rain \\
\hline 130.00 & 1996 & Halden Creek & $\mathrm{CA}$ & $58^{\circ} 20^{\prime} 02.94^{\prime \prime} \mathrm{N}$ & $123^{\circ} 07^{\prime} 45.52^{\prime \prime} \mathrm{W}$ & clay \\
\hline 131.00 & $10000 \mathrm{BP}$ & Åknes & NO & $62^{\circ} 10^{\prime} 37.29^{\prime \prime} \mathrm{N}$ & $006^{\circ} 59^{\prime} 47.45^{\prime \prime} \mathrm{E}$ & - \\
\hline 132.00 & $10000 \mathrm{BP}$ & Kykula & SK & $49^{\circ} 26^{\prime} 32.86^{\prime \prime} \mathrm{N}$ & $018^{\circ} 57^{\prime} 52.44^{\prime \prime} \mathrm{E}$ & - \\
\hline 133.00 & paleo & Latagualla & $\mathrm{CL}$ & $19^{\circ} 15^{\prime} 25.20^{\prime \prime} \mathrm{S}$ & $069^{\circ} 35^{\prime} 42.00^{\prime \prime} \mathrm{W}$ & EQ (?) \\
\hline 134.00 & $1920-12-16$ & Huihuichuan & $\mathrm{CN}$ & $35^{\circ} 57^{\prime} 07.79^{\prime \prime} \mathrm{N}$ & $105^{\circ} 40^{\prime} 07.55^{\prime \prime} \mathrm{E}$ & Gansu EQ \\
\hline 135.00 & 1980 & Amloke Nakka & PK & $34^{\circ} 34^{\prime} 25.76^{\prime \prime} \mathrm{N}$ & $073^{\circ} 08^{\prime} 40.24^{\prime \prime} \mathrm{E}$ & clay \\
\hline 136.00 & $1960-10$ & Tessina & IT & $46^{\circ} 11^{\prime} 21.78^{\prime \prime} \mathrm{N}$ & $012^{\circ} 24^{\prime} 08.15^{\prime \prime} \mathrm{E}$ & - \\
\hline 137.00 & paleo & Krynica & PL & $49^{\circ} 25^{\prime} 01.78^{\prime \prime} \mathrm{N}$ & $020^{\circ} 57^{\prime} 38.80^{\prime \prime} \mathrm{E}$ & deglaciation \\
\hline 138.00 & paleo & Collinabos & $\mathrm{BE}$ & $50^{\circ} 46^{\prime} 11.40^{\prime \prime} \mathrm{N}$ & $003^{\circ} 34^{\prime} 34.26^{\prime \prime} \mathrm{E}$ & loess \\
\hline 139.00 & 2002-09-06 & Cerda & IT & $37^{\circ} 56^{\prime} 03.10^{\prime \prime} \mathrm{N}$ & $013^{\circ} 50^{\prime} 09.54^{\prime \prime} \mathrm{E}$ & Cerda EQ \\
\hline 140.00 & 2011-09-16 & Shibangou & $\mathrm{CN}$ & $32^{\circ} 14^{\prime} 27.00^{\prime \prime} \mathrm{N}$ & $106^{\circ} 44^{\prime} 45.00^{\prime \prime} \mathrm{E}$ & rain \\
\hline 141.00 & 1996-04-28 & Quesnel Forks & $\mathrm{CA}$ & $52^{\circ} 39^{\prime} 36.09^{\prime \prime} \mathrm{N}$ & $121^{\circ} 40^{\prime} 12.02^{\prime \prime} \mathrm{W}$ & rain \\
\hline 142.00 & $?$ & Riou-Bourdoux Valley & FR & $44^{\circ} 25^{\prime} 06.29^{\prime \prime} \mathrm{N}$ & $006^{\circ} 37^{\prime} 20.21^{\prime \prime} \mathrm{E}$ & rain \\
\hline 143.00 & 2000-11-18 & Slano Blato & SI & $45^{\circ} 54^{\prime} 55.45^{\prime \prime} \mathrm{N}$ & $013^{\circ} 51^{\prime} 49.12^{\prime \prime} \mathrm{E}$ & rain \\
\hline 144.00 & $1958-07-10$ & Lituya Bay & US & $58^{\circ} 40^{\prime} 53.44^{\prime \prime} \mathrm{N}$ & $137^{\circ} 29^{\prime} 11.39^{\prime \prime} \mathrm{W}$ & Alaska EQ \\
\hline 145.00 & 1976-05-06 & Mt. Boscatz & IT & $46^{\circ} 17^{\prime} 19.52^{\prime \prime} \mathrm{N}$ & $013^{\circ} 04^{\prime} 37.20^{\prime \prime} \mathrm{E}$ & Friuli EQ \\
\hline 146.00 & 1949 & Kualiangzi & $\mathrm{CN}$ & $30^{\circ} 39^{\prime} 01.00^{\prime \prime} \mathrm{N}$ & $104^{\circ} 53^{\prime} 40.00^{\prime \prime} \mathrm{E}$ & rain \\
\hline 147.00 & 6th cent. & Ropice & $\mathrm{CZ}$ & $49^{\circ} 36^{\prime} 18.57^{\prime \prime} \mathrm{N}$ & $018^{\circ} 35^{\prime} 08.10^{\prime \prime} \mathrm{E}$ & - \\
\hline 148.00 & 1982 & La Valette & FR & $44^{\circ} 24^{\prime} 40.11^{\prime \prime} \mathrm{N}$ & $006^{\circ} 38^{\prime} 52.84^{\prime \prime} \mathrm{E}$ & rain, flysch \\
\hline 149.00 & postglacial & Heather Hill & $\mathrm{CA}$ & $51^{\circ} 26^{\prime} 52.08^{\prime \prime} \mathrm{N}$ & $117^{\circ} 28^{\prime} 24.24^{\prime \prime} \mathrm{W}$ & deglaciation \\
\hline 150.00 & $2008-11-23$ & Gongjiafang & $\mathrm{CH}$ & $31^{\circ} 03^{\prime} 57.62^{\prime \prime} \mathrm{N}$ & $109^{\circ} 55^{\prime} 11.88^{\prime \prime} \mathrm{E}$ & GW \\
\hline 151.00 & paleo & Utiku & $\mathrm{NZ}$ & $39^{\circ} 44^{\prime} 51.09^{\prime \prime} \mathrm{S}$ & $175^{\circ} 50^{\prime} 16.88^{\prime \prime} \mathrm{E}$ & - \\
\hline 152.00 & paleo & Taihape & $\mathrm{NZ}$ & $39^{\circ} 40^{\prime} 56.56^{\prime \prime} \mathrm{S}$ & $175^{\circ} 47^{\prime} 30.16^{\prime \prime} \mathrm{E}$ & - \\
\hline 153.01 & paleo & Stromboli & IT & $38^{\circ} 47^{\prime} 46.85^{\prime \prime} \mathrm{N}$ & $015^{\circ} 12^{\prime} 27.06^{\prime \prime} \mathrm{E}$ & volcanism \\
\hline 153.02 & paleo & La Fossa & IT & $38^{\circ} 24^{\prime} 39.37^{\prime \prime} \mathrm{N}$ & $014^{\circ} 58^{\prime} 02.48^{\prime \prime} \mathrm{E}$ & volcanism \\
\hline 154.00 & $1909-11$ & East Lirio & PA & $09^{\circ} 02^{\prime} 21.69^{\prime \prime} \mathrm{N}$ & $079^{\circ} 39^{\prime} 02.93^{\prime \prime} \mathrm{W}$ & excavation work \\
\hline 155.01 & $2010-11$ & Cischele & IT & $45^{\circ} 42^{\prime} 42.50^{\prime \prime} \mathrm{N}$ & $011^{\circ} 13^{\prime} 24.67^{\prime \prime} \mathrm{E}$ & - \\
\hline 155.02 & $?$ & Ochojno & PL & $49^{\circ} 57^{\prime} 39.36^{\prime \prime} \mathrm{N}$ & $019^{\circ} 57^{\prime} 15.56^{\prime \prime} \mathrm{E}$ & - \\
\hline 156.00 & postglacial & Gammajunni 3 & NO & $69^{\circ} 28^{\prime} 48.90^{\prime \prime} \mathrm{N}$ & $020^{\circ} 33^{\prime} 39.86^{\prime \prime} \mathrm{E}$ & - \\
\hline 157.00 & postglacial & La Frasse & $\mathrm{CH}$ & $46^{\circ} 21^{\prime} 31.21^{\prime \prime} \mathrm{N}$ & $007^{\circ} 02^{\prime} 10.04^{\prime \prime} \mathrm{E}$ & - \\
\hline 158.00 & $1953-01-31$ & Miramar & UK & $51^{\circ} 22^{\prime} 22.79^{\prime \prime} \mathrm{N}$ & $001^{\circ} 09^{\prime} 17.08^{\prime \prime} \mathrm{E}$ & clay \\
\hline 159.00 & $?$ & Mahouane Dam & $\mathrm{DZ}$ & $36^{\circ} 17^{\prime} 24.02^{\prime \prime} \mathrm{N}$ & $005^{\circ} 21^{\prime} 24.67^{\prime \prime} \mathrm{E}$ & clay \\
\hline 160.00 & paleo & Pianello & IT & $41^{\circ} 14^{\prime} 48.93^{\prime \prime} \mathrm{N}$ & $015^{\circ} 20^{\prime} 25.04^{\prime \prime} \mathrm{E}$ & clay \\
\hline
\end{tabular}


Table A1. Cont.

\begin{tabular}{|c|c|c|c|c|c|c|}
\hline No. & Date & Landslide & C. & Latitude & Longitude & Trigger \\
\hline 161.00 & 2011 & St. Maria Maddalena & IT & $44^{\circ} 13^{\prime} 05.72^{\prime \prime} \mathrm{N}$ & $011^{\circ} 11^{\prime} 37.98^{\prime \prime} \mathrm{E}$ & tunneling \\
\hline 162.00 & $?$ & Zhaoshuling & $\mathrm{CN}$ & $31^{\circ} 02^{\prime} 38.04^{\prime \prime} \mathrm{N}$ & $110^{\circ} 20^{\prime} 46.82^{\prime \prime} \mathrm{E}$ & GW \\
\hline 163.00 & $?$ & Dúrcal & ES & $36^{\circ} 55^{\prime} 57.60^{\prime \prime} \mathrm{N}$ & $003^{\circ} 31^{\prime} 42.36^{\prime \prime} \mathrm{W}$ & - \\
\hline 164.00 & 1935 & Aggenalm & $\mathrm{DE}$ & $47^{\circ} 40^{\prime} 00.28^{\prime \prime} \mathrm{N}$ & $012^{\circ} 03^{\prime} 28.04^{\prime \prime} \mathrm{E}$ & - \\
\hline 165.00 & $?$ & Huangshipan & $\mathrm{CN}$ & $31^{\circ} 54^{\prime} 16.57^{\prime \prime} \mathrm{N}$ & $106^{\circ} 36^{\prime} 53.68^{\prime \prime} \mathrm{E}$ & - \\
\hline 166.00 & postglacial & Lake Wanaka & $\mathrm{NZ}$ & $44^{\circ} 22^{\prime} 13.00^{\prime \prime} \mathrm{S}$ & $169^{\circ} 11^{\prime} 43.61^{\prime \prime} \mathrm{E}$ & EQ (?) \\
\hline 167.00 & $2015-02-02$ & Mofjellbekken & $\mathrm{NO}$ & $59^{\circ} 28^{\prime} 10.11^{\prime \prime} \mathrm{N}$ & $010^{\circ} 18^{\prime} 02.55^{\prime \prime} \mathrm{E}$ & clay \\
\hline 168.00 & $?$ & Badu & $\mathrm{CN}$ & $24^{\circ} 42^{\prime} 36.27^{\prime \prime} \mathrm{N}$ & $105^{\circ} 47^{\prime} 56.88^{\prime \prime} \mathrm{E}$ & excavation work \\
\hline 169.01 & paleo & Number 1 & $\mathrm{CN}$ & $26^{\circ} 57^{\prime} 25.06^{\prime \prime} \mathrm{N}$ & $102^{\circ} 57^{\prime} 54.94^{\prime \prime} \mathrm{E}$ & - \\
\hline 169.02 & paleo & Number 2 & $\mathrm{CN}$ & $27^{\circ} 00^{\prime} 10.31^{\prime \prime} \mathrm{N}$ & $102^{\circ} 52^{\prime} 53.13^{\prime \prime} \mathrm{E}$ & - \\
\hline 170.01 & $2005-12-10$ & Saint Barnabé & $\mathrm{CA}$ & $46^{\circ} 22^{\prime} 48.83^{\prime \prime} \mathrm{N}$ & $072^{\circ} 49^{\prime} 24.93^{\prime \prime} \mathrm{W}$ & clay \\
\hline 170.02 & 2010-05-10 & Saint Jude & CA & $45^{\circ} 48^{\prime} 16.72^{\prime \prime} \mathrm{N}$ & $072^{\circ} 57^{\prime} 49.13^{\prime \prime} \mathrm{W}$ & clay \\
\hline 170.03 & 1994-04-21 & Sainte Monique & CA & $46^{\circ} 10^{\prime} 41.46^{\prime \prime} \mathrm{N}$ & $072^{\circ} 33^{\prime} 05.56^{\prime \prime} \mathrm{W}$ & clay \\
\hline 171.00 & 1970 & Bird & $\mathrm{NZ}$ & $39^{\circ} 37^{\prime} 54.07^{\prime \prime} \mathrm{S}$ & $175^{\circ} 49^{\prime} 38.10^{\prime \prime} \mathrm{E}$ & - \\
\hline 172.00 & 2013-12-03 & Montescaglioso & IT & $40^{\circ} 32^{\prime} 31.06^{\prime \prime} \mathrm{N}$ & $016^{\circ} 39^{\prime} 10.96^{\prime \prime} \mathrm{E}$ & - \\
\hline 173.00 & 19th cent. & Spriana & IT & $46^{\circ} 12^{\prime} 41.31^{\prime \prime} \mathrm{N}$ & $009^{\circ} 52^{\prime} 30.02^{\prime \prime} \mathrm{E}$ & - \\
\hline 174.00 & $?$ & Piscopio I Tunnel & IT & $38^{\circ} 47^{\prime} 05.67^{\prime \prime} \mathrm{N}$ & $016^{\circ} 33^{\prime} 03.52^{\prime \prime} \mathrm{E}$ & tunneling \\
\hline 175.00 & $?$ & La Saxe & IT & $45^{\circ} 49^{\prime} 02.33^{\prime \prime} \mathrm{N}$ & $006^{\circ} 58^{\prime} 13.17^{\prime \prime} \mathrm{E}$ & - \\
\hline 176.00 & $?$ & Erguxi & $\mathrm{CN}$ & $31^{\circ} 35^{\prime} 59.57^{\prime \prime} \mathrm{N}$ & $102^{\circ} 49^{\prime} 06.14^{\prime \prime} \mathrm{E}$ & - \\
\hline 177.01 & $1955-12-07$ & Hawkesbury & CA & $45^{\circ} 34^{\prime} 49.52^{\prime \prime} \mathrm{N}$ & $074^{\circ} 32^{\prime} 47.16^{\prime \prime} \mathrm{W}$ & blast (?) \\
\hline 177.02 & $1962-05-23$ & Toulnustouc & CA & $49^{\circ} 57^{\prime} 47.64^{\prime \prime} \mathrm{N}$ & $068^{\circ} 08^{\prime} 42.84^{\prime \prime} \mathrm{W}$ & blast (?) \\
\hline 177.03 & 1996-06-20 & Finneidfjord & $\mathrm{NO}$ & $66^{\circ} 10^{\prime} 55.96^{\prime \prime} \mathrm{N}$ & $013^{\circ} 47^{\prime} 44.52^{\prime \prime} \mathrm{E}$ & blast (?) \\
\hline 177.04 & 2009-03-13 & Kattmarka & $\mathrm{NO}$ & $64^{\circ} 28^{\prime} 26.16^{\prime \prime} \mathrm{N}$ & $011^{\circ} 26^{\prime} 06.42^{\prime \prime} \mathrm{E}$ & blast (?) \\
\hline 177.05 & 2009-08-01 & La Romaine & CA & $50^{\circ} 13^{\prime} 24.23^{\prime \prime} \mathrm{N}$ & $060^{\circ} 40^{\prime} 14.07^{\prime \prime} \mathrm{W}$ & blast (?) \\
\hline 178.01 & 1960 & Bumper & AU & $37^{\circ} 40^{\prime} 52.09^{\prime \prime} \mathrm{S}$ & $145^{\circ} 53^{\prime} 55.81^{\prime \prime} \mathrm{E}$ & rain \\
\hline 178.02 & 1960 & Siphon Gully & AU & $37^{\circ} 41^{\prime} 10.59^{\prime \prime} \mathrm{S}$ & $145^{\circ} 54^{\prime} 11.54^{\prime \prime} \mathrm{E}$ & rain \\
\hline
\end{tabular}

\section{References}

1. Bird, J.F.; Bommer, J.J. Earthquake losses due to ground failure. Eng. Geol. 2004, 75, 147-179. [CrossRef]

2. Froude, M.J.; Petley, D.N. Global fatal landslide occurrence from 2004 to 2016. Nat. Hazards Earth Syst. 2018, 18, 2161-2181. [CrossRef]

3. Ciurleo, M.; Mandaglio, M.C.; Moraci, N. Landslide susceptibility assessment by TRIGRS in a frequently affected shallow instability area. Landslides 2019, 16, 175-188. [CrossRef]

4. USGS. Landslide Types and Processes. United States Geological Survey Fact Sheet 2004, 3072, 4. Available online: https://pubs.usgs.gov/fs/2004/3072/pdf/fs2004-3072.pdf (accessed on 25 October 2019).

5. Lott, N.; McCown, S.; Graumann, A.; Ross, T.; Lackey, M. Hurricane Mitch 1999-The Deadliest Atlantic Hurricane since 1780; National Climatic Data Center of the National Oceanic and Atmospheric Administration: Asheville, NC, USA, 1999. Available online: ftp://ftp.ncdc.noaa.gov/pub/data/extremeevents/specialreports/ Hurricane-Mitch-1998.pdf (accessed on 8 October 2019).

6. Yin, Y.P.; Wang, F.W.; Sun, P. Landslide hazards triggered by the 2008 Wenchuan earthquake, Sichuan, China. Landslides 2009, 6/2, 139-151. [CrossRef]

7. Harp, E.L.; Jibson, R.W. Inventory of landslides triggered by the 1994 Northridge, California earthquake. United States Geol. Surv. Open File Rep. 1995, 95, 17. Available online: https://geo-nsdi.er.usgs.gov/metadata/ open-file/95-213/ (accessed on 20 May 2020).

8. Harp, E.L.; Jibson, R.L. Landslides triggered by the 1994 Northridge, California earthquake. Bull. Seismol. Soc. Am. 1996, 86, S319-S332.

9. Keefer, D.K. Landslides caused by earthquakes. Bull. Geol. Soc. Am. 1984, 9, 406-421. [CrossRef]

10. Prestininzi, A.; Romeo, R. Earthquake-induced ground failures in Italy. Eng. Geol. 2000, 58, 387-397. [CrossRef]

11. Rodríguez, C.E.; Bommer, J.J.; Chandler, R.J. Earthquake-induced landslides: 1980-1997. Soil Dyn. Earthq. Eng. 1999, 18, 325-346. [CrossRef]

12. Tanyaş, H.; Van Westen, C.J.; Allstadt, K.E.; Nowicki Jessee, M.A.; Görüm, T.; Jibson, R.W.; Godt, J.W.; Sato, H.P.; Schmitt, R.G.; Marc, O.; et al. Presentation and Analysis of a Worldwide Database of Earthquake-Induced Landslide Inventories. J. Geophys. Res. Earth Surf. 2017, 122, 1991-2015. [CrossRef] 
13. Cardinali, M.; Ardizzone, F.; Galli, M.; Guzzetti, F.; Reichenbach, P. Landslides triggered by rapid snow melting: The December 1996-January 1997 event in Central Italy. In Proceedings of the 1st Plinius Conference, Maratea, Italy, 14-16 October 1999; Claps, P., Siccardi, F., Eds.; Bios Publisher: Cosenza, Italy, 2000; pp. 439-448.

14. Schlögel, R.; Torgoev, I.; De Marneffe, C.; Havenith, H.B. Evidence of a changing size-frequency distribution of landslides in the Kyrgyz Tien Shan, Central Asia. Earth Surf. Proc. Land. 2011, 36/12, 1658-1669. [CrossRef]

15. Bucknam, R.C.; Coe, J.A.; Chavarria, M.M.; Godt, J.W.; Tarr, A.C.; Bradley, L.A.; Rafferty, S.; Hancock, D.; Dart, R.L.; Johnson, M.L. Landslides Triggered by Hurricane Mitch in Guatemala-Inventory and Discussion. United States Geol. Surv. Open File Rep. 2001, 443, 40. Available online: https://www.sciencebase.gov/catalog/ item/4f4e4b1be4b07f02db6a91b2 (accessed on 20 May 2020). [CrossRef]

16. Malamud, B.D.; Turcotte, D.L.; Guzzetti, F.; Reichenbach, P. Landslide inventories and their statistical properties. Earth Surf. Proc. Landf. 2004, 29, 687-711. [CrossRef]

17. Brunetti, M.T.; Guzzetti, F.; Rossi, M. Probability distributions of landslide volumes. Nonlinear Process. Geophys. 2009, 16, 179-188. [CrossRef]

18. Guzzetti, F.; Malamud, B.D.; Turcotte, D.L.; Reichenbach, P. Power-law correlations of landslide areas in central Italy. Earth Planet. Sci. Lett. 2002, 195, 169-183. [CrossRef]

19. Guzzetti, F.; Ardizzone, F.; Cardinali, M.; Galli, M.; Reichenbach, P.; Rossi, M. Distribution of landslides in the Upper Tiber River basin, central Italy. Geomorphology 2008, 96, 105-122. [CrossRef]

20. Guzzetti, F.; Mondini, A.C.; Cardinali, M.; Fiorucci, F.; Santangelo, M.; Chang, K.T. Landslide inventory maps: New tools for an old problem. Earth-Sci. Rev. 2012, 112, 42-66. [CrossRef]

21. Korup, O. Distribution of landslides in southwest New Zealand. Landslides 2005, 2, 43-51. [CrossRef]

22. Larsen, I.J.; Montgomery, D.R.; Korup, O. Landslide erosion controlled by hillslope material. Nat. Geosci. 2010, 3, 247-251. [CrossRef]

23. Van Den Eeckhaut, M.; Poesen, J.; Govers, G.; Verstraeten, G.; Demoulin, A. Characteristics of the size distribution of recent and historical landslides in a populated hilly region. Earth Planet. Sci. Lett. 2007, 256, 588-603. [CrossRef]

24. Guzzetti, F.; Ardizzone, F.; Cardinali, M.; Rossi, M.; Valigi, D. Landslide volumes and landslide mobilization rates in Umbria, central Italy. Earth Planet. Sci. Lett. 2009, 279, 222-229. [CrossRef]

25. Havenith, H.B.; Strom, A.; Torgoev, I.; Torgoev, A.; Lamair, L.; Ischuk, A.; Abdrakhmatov, K. Tien Shan Geohazards Database: Earthquakes and landslides. Geomorphology 2015, 249, 16-31. [CrossRef]

26. Hovius, N.; Stark, C.P.; Allen, P.A. Sediment flux from a mountain belt derived by landslide mapping. Geology 1997, 25, 231-234. [CrossRef]

27. Korup, O. Effects of large deep-seated landslides on hillslope morphology, western Southern Alps, New Zealand. J. Geophys. Res. Earth Surf. 2006, 111, 18. [CrossRef]

28. Ten Brink, U.S.; Geist, E.L.; Andrews, B.D. Size distribution of submarine landslides and its implication to tsunami hazard in Puerto Rico. Geophys. Res. Lett. 2006, 33, 4. [CrossRef]

29. Cruden, D.M.; Krahn, J. A Reexamination of the Geology of the Frank Slide. Can. Geotech. J. 1973, 10, 581-591. [CrossRef]

30. Google Earth Pro; Version 7.3.2. Frank Landslide, Canada, $49^{\circ} 35^{\prime} 19.10^{\prime \prime N} \& 114^{\circ} 23^{\prime} 39.35^{\prime \prime}$, eye altitude 2.53 km, Google 2018, CNES/Airbus 2019, 2019a; Google: Mountain View, CA, USA, 2018.

31. Domej, G.; Bourdeau, C.; Lenti, L.; Martino, S.; Pluta, K. Mean landslide geometries inferred from a global database of earthquake- and non-earthquake-triggered landslides. Ital. J. Eng. Geol. Environ. 2017, 17, 87-107. [CrossRef]

32. MATLAB; Version 9.7.0 (R2019b); The MathWorks Inc.: Natick, MA, USA, 2019.

33. IAEG Commission on Landslides. Suggested nomenclature for landslides. Bull. Int. Assoc. Eng. Geol. 1990, 41, 13-16. [CrossRef]

34. Cruden, D.M.; Varnes, D.J. Landslide types and processes. In Landslides: Investigation and Mitigation, 1st ed.; Special Report 247; Turner, A.K., Schuster, R.L., Eds.; National Research Council, Transportation Research Board: Washington, DC, USA, 1996; pp. 36-75.

35. Delgado, J.; Garrido, J.; Lenti, L.; Lopez-Casado, C.; Martino, S.; Sierra, F.J. Unconventional pseudostatic stability analysis of the Diezma landslide (Granada, Spain) based on a high-resolution engineering-geological model. Eng. Geol. 2015, 184, 81-95. [CrossRef]

36. Google Earth Pro; Version 7.3.2. Diezma Landslide, Spain, $37^{\circ} 18^{\prime} 34.00^{\prime \prime} \mathrm{N} \& 3^{\circ} 22^{\prime} 8.70^{\prime \prime} \mathrm{W}$, eye altitude $2.03 \mathrm{~km}$, Google 2018, Europa Technologies 2018, 2019b; Google: Mountain View, CA, USA, 2018. 
37. Varnes, D.J. Slope movement types and processes. In Landslides-Analysis and Control, 1st ed.; Special Report 176; Schuster, R.L., Krizek, R.J., Eds.; National Research Council, Transportation Research Board: Washington, DC, USA, 1978; pp. 11-33.

38. Stark, C.P.; Guzzetti, F. Landslide rupture and the probability distribution of mobilized debris volumes. J. Geophys. Res. Earth 2009, 114, 16. [CrossRef]

39. Heim, A. Bergsturz und Menschenleben, Beiblatt zur Vierteljahrsschrift der Naturforschenden Gesellschaft in Zürich no. 20; Fretz \& Wasmuth: Tübingen, Germany, 1932; p. 218.

40. Domej, G. Seismically Induced Effects and Slope Stability In Urbanized Zones by Numerical Modeling. Ph.D. Thesis, Institut Français des Sciences et Technologies des Transports, de l'Aménagement et des Réseaux \& Université Paris-Est, Paris, France, 2018; p. 266.

41. ISO. ISO 3166 Country Codes; International Organization for Standardization: Geneva, Switzerland, 2013. Available online: https://www.iso.org/iso-3166-country-codes.html (accessed on 25 October 2019).

C 2020 by the authors. Licensee MDPI, Basel, Switzerland. This article is an open access article distributed under the terms and conditions of the Creative Commons Attribution (CC BY) license (http://creativecommons.org/licenses/by/4.0/). 